\title{
1 Climate changes during the Early-Middle Triassic transition in the E. Iberian \\ 2 plate and their palaeogeographic significance in the western Tethys continental \\ 3 domain
}

4 Violeta Borruel-Abadía ${ }^{\mathrm{a}}$, José López-Gómez ${ }^{\mathrm{a}}$, Raúl De la Horra ${ }^{\mathrm{b}}$, Belén Galán-

5 Aballán $^{\mathrm{b}}$, José F. Barrenechea ${ }^{\mathrm{a}, \mathrm{c}}$, Alfredo Arche ${ }^{\mathrm{a}}$, Ausonio Ronchi ${ }^{\mathrm{d}}$, Nicola Gretter ${ }^{\mathrm{d}}$,

6 Mariano Marzo ${ }^{\mathrm{e}}$

7 a Instituto de Geociencias (CSIC, UCM), C/José Antonio Nováis 12, 28040 Madrid, Spain.

$8 \quad{ }^{\mathrm{b}}$ Dept. of Stratigraphy, Faculty of Geology, Universidad Complutense de Madrid, 28040 Madrid, Spain.

$9{ }^{\mathrm{c}}$ Dept. of Crystallography and Mineralogy, Faculty of Geology, Universidad Complutense de Madrid, 1028040 Madrid, Spain.

$11{ }^{\mathrm{d}}$ Dept. of Earth and Environmental Sciences, University of Pavia, Via Ferrata 1, 27100 Pavia, Italy.

$12{ }^{\mathrm{e}}$ Dept. of Stratigraphy, Palaeontology and Marine Geosciences, Faculty of Geology, Universitat de 13 Barcelona, 08028 Barcelona, Spain.

15 * Corresponding author: Instituto de Geociencias (CSIC, UCM), C/José Antonio Novais 12, 28040

16 Madrid, Spain. Fax: +34 91 39444808, Telephone: + 3491 3944783, E-mail: jlopez@ geo.ucm.es (J.

17 López-Gómez)

\section{Abstract}

19 Until recently the climate of the Early-Middle Triassic at low latitudes was broadly considered as generally temperate-warm with no major climate oscillations. This work examines the climate of this period through a detailed study of the sedimentary, plant, soil and mineral records of continental rocks (Buntsandstein facies) in eastern Iberian basins. Our findings indicate temporal climate variations for these near equator $\left(10^{\circ}-\right.$ $14^{\circ} \mathrm{N}$ ) regions and unveil the significance of such variations in the southern Laurasian domain. 
The climate of Iberia's Early Triassic was mainly dominated by alternating brief $(<0.4$ ma) arid and semi-arid climate periods, with two main arid periods documented at the end of the Smithian and middle Spathian. However, an initial short subhumid to semiarid period was also observed in the late Spathian. Remarkably, this latter period appears just after an unconformity related to the tectonically induced Hardegsen Event in western Europe. It is also of interest that this short subhumid climate period is concurrent with the beginning of faunal and floral recovery in the basins examined. The Early Triassic ended again with a short very arid period.

Although the beginning of the Anisian (Aegean) was represented by alternating arid and semi-arid to subhumid intervals, during the Bithynian and Pelsonian clearly wetter climates are recorded by the succession consisting of alternating semi-arid to semihumid intervals. This general tendency was interrupted by three short but marked intervals, two humid intervals in the late Bithynian, and one arid period near the Bithynian/Pelsonian boundary.

Iberia was crossed by prominent irregular highs separating marked corridors or isolated areas. This palaeogeography, prevailing since Variscan tectonics, clearly conditioned dominant climates and their geographical distribution. No clear climate belts developed in these conditions. However, isolated internal climate zones separated by elevated areas are identified. This palaeogeographic configuration and the low latitudinal position of Iberia determined central Iberia highs in the southernmost border of Laurasia, beyond which more humid conditions clearly extended towards the equator reaching the present-day Moroccan Meseta and Argana Basin.

Keywords: Triassic climates, Buntsandstein, Iberia, Early Triassic, Pangaea 


\section{Introduction}

The end-Permian mass extinction devastated both marine and terrestrial ecosystems (Benton, 2003; Erwin, 2006; Algeo et al., 2011). This event, besides being the most catastrophic known loss of biodiversity, was followed by an unusually long period of recovery throughout the Early Triassic (Payne et al., 2004; Kozur and Weems, 2011; Retallack et al., 2011; Benton and Newell, 2014). Takahashi et al. (in press) have even extended to the late Spathian, the global environmental perturbations that were likely responsible for the delayed recovery of life in the marine realm. However, recent studies (Hofmann et al., 2011, 2013) have also suggested that this latter idea should be abandoned.

Although there is increasing evidence indicating that this mass extinction was most probably triggered by a combination of different factors rather than a single event (Berner, 2002; Galfetti et al., 2007), numerous scenarios related to of the Siberian Traps Eruptions have been proposed (Wignall, 2001; Algeo et al., 2011; Benton and Newell, 2014), including $\mathrm{CO}_{2}$ emissions and methane release which induced global warming. Recent modelling based on carbon isotope excursions (Payne and Kump, 2007; Kearsey et al., 2009; Romano et al., 2013) supports the latter scenario.

The activity of the Siberian Traps, which continued into Early Triassic times (Nikishin et al., 2002; Payne and Kump, 2007), is interpreted to have led to enhanced greenhouse climate conditions (Retallack et al., 2011; Romano et al., 2013). Global warming is widely thought to have played an important role in biotic crises (Montañez et al., 2007; Benton and Newell, 2014). This factor is considered responsible for intensifying unfavourable conditions for recovering ecosystems during the Early Triassic (Kozur and Weems, 2011), and even described as lethal during this time (Sun 
et al., 2012). Although clear connections appear, ecosystem rebuilding and ecological recovery from this period varied between terrestrial and marine realms, and even between regions (Twitchett, 2006). Environmental stress during the Early Triassic in both realms could also have been driven by rapid change between longer intervals of global warming and shorter intervals of global cooling, as observed in faunal change studies (Kozur and Weems, 2011; Posenato, 2008). This interval of time and even the beginning of the Middle Triassic were therefore more complex and nuanced than a simple but dramatic global warming period.

Climate variations between terrestrial and marine realms and different regions were probably related to the particular palaeogeographic configuration of Pangaea (Kiehl and Shields, 2005; Sellwood and Valdes, 2007). Pangea was approximately centred on the equator, stretching almost from pole to pole and surrounded by the Panthalassa Ocean (Muttoni et al., 2009; Roscher et al., 2011) (Fig. 1). A wide oceanic gulf, the Tethys sea, latitudinally confined to the tropical-subtropical belt, developed on its eastern side. A configuration like this with a vast expanse of exposed land at low and mid-latitudes centred on the equator with a warm Tethys sea would have determined summer heating in circum-Tethyan continental areas with a strong monsoonal regime and extreme continentality. Such a continental climate would have entailed hot summers and relatively cold winters (Kutzbach and Gallimore, 1989), along with a remarkably high tropical sea-surface temperature with peaks of up to $40^{\circ} \mathrm{C}$ during the Early Triassic (Joachimski et al., 2012).

Despite intense research on the greenhouse climates of Mesozoic times, the climate of the Early Triassic has been relatively ignored until recently. Some decades ago, the Triassic climate was considered that of a general hot-house with ice free poles 
without major oscillations. However, recent interesting studies (e.g. Kidder and Worsley, 2004; Sellwood and Valdes, 2007; Galfetti et al., 2007; Twitchett, 2007; Preto et al., 2010; Stefani et al., 2010; Retallack et al., 2011; Bourquin et al., 2011; Sun et al., 2012; Romano et al., 2013; Benton and Newell, 2014, among others) have revealed a more complex scenario with climate oscillations, non-zonal patterns and presence of a global monsoon system.

This contribution considers climate variation over the late Early Triassic - early Middle Triassic time-interval in the Iberian Plate and adjacent areas, its features and palaeogeographical aftermath in the Western Tethys continental realm. Specifically, we examined the effects of these variations on terrestrial life and relationships with pertinent environmental changes and compared our data with those already described for nearby palaeolatitudinal areas.

\section{Geologic and stratigraphic setting.}

During the Early Triassic, the Iberian plate occupied the eastern flank of the Pangea supercontinent (Fig. 1A) as a small plate close to the southernmost part of the ancient Laurasia megacontinent (Ziegler and Stampfli, 2001; Stampfli and Borel, 2002; Muttoni et al., 2009; Domeier et al., 2012). During the Early Permian, different basins developed on the eastern side of the plate, while the western portion remained stable to form what today constitutes the so-called Hercynian Massif. Basins initially developed as small isolated troughs, but later these gave rise to a complex system of interconnected rift basins in Central and Western Europe during the Early Triassic (van Wees et al., 1998; De Vicente et al., 2009). 

and Pyrenean-Cantabrian basins, or their respective present-day ranges after Cenozoic inversion (Fig. 1B). Some other small basins contemporaneously developed east of the Iberian plate in present-day Sardinia and the Balearic Islands (Ramos, 1995; Bercovici et al., 2009; Cassinis et al., 2003) and show a similar sedimentary record for the Earlyearly Middle Triassic (Bourquin et al., 2007, 2011; Cassinis et al., 2012; López-Gómez et al., 2012; Galán-Abellán et al., 2013a; Ronchi et al., 2014) (Fig 2). It basically consists of a succession of two-three units of continental origin, each representing one tectono-sedimentary sequence related to different reactivation phases of the rift systems that developed during the Permian (Arche and López-Gómez, 1996; van Wees et al., 1998; Vargas et al., 2009). The succession shows a general fining-upward tendency, and the units may be separated by hiatuses. This continental sedimentary sequence ends with the westward ingression of the Tethys sea across these areas during the middle Anisian (Ziegler, 1988; Kozur and Bachmann, 2008; Bourquin et al., 2011; EscuderoMozo et al., 2015). outcrops of the different basins. However, when they do appear, they show similar 137 sedimentary characteristics and lateral continuity. As across most of Western Europe, 138 the beginning of the Triassic sedimentary cycle is marked by an unconformity on the Upper Permian rocks, representing a time-span of 6-10 m.a. (Bourquin et al., 2011) to 15 m.a. (Durand, 2006). 

Ranges comprises three lithostratigraphic units (Fig. 2): Valdemeca Conglomerates Unit (VC), Cañizar Sandstones Fm. (CS), and Eslida Mudstones and Sandstones Fm. (EMS).

The Valdemeca Unit was initially considered as the lower subunit of the Cañizar Fm. (López-Gómez and Arche, 1993) but later defined as a single unit (De la Horra et al., 2005).

The Cañizar Fm. mostly consists of red-pink, medium-grain arkoses, 80-110 m thick, and laterally corresponds to the Rillo the Gallo Fm. to the west. This formation has been divided into six subunits ( $\mathrm{C} 1$ to $\mathrm{C} 6)$ separated by major boundary surfaces (mbs) laterally recognized over hundred kilometres (López-Gómez et al., 2012) (Fig. 3A). It is interpreted as sandy braided fluvial deposits, with some aeolian reworking, evolving to dominantly aeolian deposits in the northern and eastern zones (Soria et al., 2011; López-Gómez et al., 2011). The upper subunits (C5 and C6) are separated from the rest by a prominent major boundary surface (mbs-5) that marks the reactivation of sedimentation and development of a more energetic fluvial system in most of the Iberian Ranges (López-Gómez et al., 2012).

The Eslida Fm. consists of red siltstones and intercalated decimetric sandstone bodies of arkosic composition (Fig. 3B). The formation's thickness is up to $660 \mathrm{~m}$, thinning to the SE and NW, and it is subdivided into six subunits (Ems-1 to Ems-6) based on their sedimentary characteristics (Arche and López-Gómez, 1999). The unit was deposited only in the central-eastern Iberian Ranges, as the western and easternmost areas of the Iberian Basin were elevated during the time of deposition, while the central area experienced intense subsidence (Arche and López-Gómez, 2005). This geographical arrangement has determined marked lateral thickness variations (Fig. 
167 2). As a result of this control, in the sections examined here only the four younger 168 subunits (Ems-3 to Ems-6) of the Eslida Fm. were deposited. The transition of the 169 Eslida Fm. to the first deposits of marine origin is represented by Röt facies, the so170 called Marines Fm. (M) in this area, mostly identified through marls, clays and gypsum 171 (Arche and López-Gómez, 1999).

\subsection{Pyrenean Ranges}

The beginning of the Triassic continental cycle in the E. Pyrenees (so-called 175 Catalan Pyrenees) was broadly defined as the "Buntsandstein cycle" by Gisbert (1981, 1983), without more detailed subdivisions (Fig. 2). This cycle, which shows an average thickness of about $200 \mathrm{~m}$ across the whole area considered, lies, via a marked angular unconformity $\left(30^{\circ}-60^{\circ}\right)$, on Permian rocks (Mey et al., 1968; Naetegaal et al., 1969; Gisbert, 1981; Ronchi et al., 2014; Gretter, 2014). The lowermost part of the Buntsandstein consists of coarse-grained conglomerates with deeply erosive base (i.e. the Iguerri member of Nagtegaal et al., 1969) and sandstones of gravel braided fluvial systems, channel and aeolian sand-sheets. Overlying these base layers, the upper portion of the Buntsandstein is composed of reddish sandstones, bioturbated mudstones and siltstones of a playa lake environment. Near the top, siltstones and claystones locally change into dark red fine levels until the contact with the Muschelkalk sequence. These "transition" layers probably represent the Röt facies in the Catalan Pyrenees. The contact between the upper fine deposits and dolomites of the first marine incursion probably represents a hiatus that lasts until the Anisian (Escudero-Mozo et al., 2014). 


\subsection{Catalan Ranges}

The beginning of the Triassic continental sedimentary cycle in the Catalan Ranges is differently represented in the three sectors into which the ranges were subdivided (Calvet and Marzo, 1994). The cycle features three units in each of the three sectors, represented in sections 6,7 and 8 (Fig. 2), that are broadly considered timeequivalent (Galán-Abellán et al., 2013a). These units, which change in name from south to north, were initially described by Marzo (1986) and more recently by Galán-Abellán et al. (2013a). They are (Fig. 2): Prades Upper Conglomerates (PUC), Prades Lower Sandstones (PLS), and Aragall Sandstones and Mudstones (ASM) in the southern sector; Garraf Upper Conglomerates (GUC), Eramprunyà Sandstones (ES) and Aragall Sandstones and Mudstones (ASM) in the central sector; and Riera de San Jaume Sequence (RSJ) and the Figaró Mudstones and Sandstones (FMS) in the northern sector. The Prades Conglomerates unit, Garraf Conglomerates unit and the lower part of the San Jaume Sequence were interpreted as deposited by gravelly braided fluvial systems related to proximal alluvial fans. The Prades Sandstones unit was interpreted as fluvio-aeolian deposits, the Eramprunyà Sandstones unit as sandy braided fluvial deposits with intercalated aeolian sandstones, and the upper part of the San Jaume Sequence as sandy braided fluvial deposits. The Aragall and Figarò units were interpreted as mixed-load, sinuous, fluvial systems developed in wide muddy floodplains deposits (Marzo, 1980).

\subsection{Sedimentary cycle age}



palynological assemblages obtained in the Cañizar and Eslida Fms., as well as in the overlying Marines Fm. (Boulouard and Viallard, 1982; Doubinger et al., 1990; Díez et al., 2010), and according to one foraminifer association obtained in, the Landete Fm. (Escudero-Mozo et al., 2015). The base of the Valdemeca Unit has been dated as Smithian, the uppermost Cañizar Fm. is Aegean in age, and the uppermost Eslida Fm. Bithynian (López-Gómez et al., 2012) (Fig. 2). record that consists of a Pleuromeia plant specimen in the uppermost part of the Eramprunyà Unit (Galán-Abellán et al., 2013a), and some isolated footprints reptiles and fragments of bones in the El Figarò Unit (Gaete et al., 1994; Fortuny et al., 2011). These are neither sufficient nor representative to indicate the precise age of the beginning of this sedimentation cycle. Díez et al. (2013) examined a pollen assemblage above this cycle, in the Upper Evaporitic Unit (UE) or Röt facies, indicating a Bithynian-Pelsonian age. A magnetostratigraphic study of the cycle in the Riera de San Jaume Sequence (RSJ in Fig. 2) (Dinarès-Turell et al., 2005), assigns the lower part of the cycle to the Spathian and the upper part to the Illyrian. Finally, a precise Pelsonian age obtained for Ammonites in the marine carbonate sediments just above this continental cycle (Escudero-Mozo et al., 2014) (Fig. 2), point roughly to an equivalence between this sedimentary cycle and the one described for the Iberian Ranges.

In the E Pyrenees, an early Anisian age based on palynomorph assemblages (Broutin et al., 1988; Calvet et al., 1993; Díez, 2000; Díez et al., 2005) was obtained for the upper dark red fine clastic deposits of the "Buntsandstein cycle". Based on these palynological studies, we attribute the lower coarser part of this sedimentary cycle a late 
236 Early Triassic age. Thus, the age of this cycle, as well as its general lithological 237 succession would be broadly time-equivalent to those described in both the Iberian and 238 Catalan Ranges (Fig. 2).

\section{Methods}

The multidisciplinary approach used includes a stratigraphic and sedimentologic

242 study, palaeosol characterisation, and a description of the palaeontologic contents and

243 petrology of fine sediments. Figure 4 shows a scheme of the general data described for

244 the units in the different areas. Given strong correlation between the genesis of many sedimentary rocks and climate change, our stratigraphic and sedimentologic descriptions and interpretations of the units, are based, among other data, on those which allow to obtain temperature, wind direction and precipitation information. Despite the difficulty in obtaining precise ages of continental Triassic rocks, detailed stratigraphic information is necessary as climate change can occur over short time scales, and some continental deposits will not record a specific climate event, as accretion may be very slow (Benton and Newell, 2014).

Based on plant fossils and sediments, our goal was to reconstruct climate variations throughout each unit. This approach was able to identify, for example, correlations between the ecology and growth of floras and different alluvial environments. Preserved palaeosols were used as proxies for precipitation trends and climate seasonality. Further, clay minerals in the profiles examined were used as additional evidence of climate control, as different clay minerals form by chemical weathering under different humidity conditions. Finally, vertebrate ichnites and an 
259 isolated insect data were also used for palaeogeographic reconstruction. All these data

260 were compared with those from near Tethys areas to construct plausible 261 palaeogeographic scenarios for the studied time-interval.

\section{The sedimentary record}

\subsection{Stratigraphy and sedimentology}

Our sedimentologic analysis was mostly based on data from prior work on these units, which are here synthesized. Ten selected sections were examined in detail: five in the E Iberian Ranges, two in the E Pyrenees and three in the Catalan Ranges (Fig. 5). Sections commonly show large thickness variations among the different basins. Sedimentation-free areas occur at the basin margins, while prominent depocentres developed away from those areas, where the sedimentary record may approach $400 \mathrm{~m}$ in thickness. All sections of the three basins show a hiatus that roughly corresponds to the Aegean but also to the early Bithynian in some cases. This time-span without sedimentation grossly separates coarser from finer siliciclastic sediments, probably

274 related to general plate reorganization, as discussed below.

The depositional systems corresponding to these units were reconstructed through detailed sedimentologic facies description and interpretation. Different architectural elements were also based on facies associations, their hierarchies and stacking pattern characteristics.

The study of the units allowed us to differentiate 19 facies and eight associated or secondary facies. Some of these facies are described according to Miall's nomenclature (1992, 1996); all are summarized in figure 6. Thirteen facies were 
ascribed to alluvial sediments, while six (ae1 to ae6) were differentiated into aeolian sediments. These latter facies are locally completed with eight secondary or associated facies.

The facies described as alluvial sediments are basically represented by sandstones, conglomerates or both, while those described in aeolian sediments are basically comprised of sandstones.

Facies and associations between them constitute sedimentary bodies or architectural elements (sensu Miall, 1992, 1996), each with a particular external geometry and internal vertical stacking pattern. Sedimentary environments were reconstructed from the analysis and interpretation of these architectural elements. Nine architectural elements identified across the studied units are summarized in figure 7. Six of these elements were related to a fluvial sedimentary environment, and the remaining three to an aeolian sedimentary environment.

The fluvial sedimentary environment includes megaripples, channel fill, lateral accretion, gravel bars, unconfined or semiconfined clast bodies and floodplain architectural elements, while the aeolian sedimentary environment includes dune, sandsheet and interdune architectural elements. The vertical succession of these elements in the studied sections (Fig. 5) reflects sedimentary evolution through the different units and the basins they filled.

Sedimentation in the basins probably started not before the early Smithian. In all cases, the general deposition trend is fining upward. This tendency is interrupted at the boundary between two main cycles of deposition (Fig. 4). The lower one, with a coarser lithology, may start with gravel bar successions (GB), normally amalgamated into 
macroforms (Fig. 8a, f). These represent gravelly braided fluvial systems with punctuate aeolian reworking in the S Iberian Ranges and Catalan Ranges. Although less frequent, the GM architectural element (Fig. 8b) may also appear in this lower part of the cycle, indicating flash floods or unconfined deposits related to arid or semi-arid climate areas (Durand, 2006, 2008; De la Horra et al., 2005, 2008, 2011; Bourquin et al., 2007, 2011). The upper part of this lower coarser cycle of deposition is basically represented by sandy braided fluvial systems (SB, CH) (Fig. 8c) intercalated into aeolian dune field complexes (E1, E2, E3) that tend to be more frequent towards the central Iberian Ranges and south Catalan Ranges (Figs. 8d, e, h and 9A). In the S Iberian Ranges, above major boundary surface 5 (mbs 5 ), clear reactivation in the general depositional system allowed for the punctate development of gravel bars in the fluvial systems and a general increase in water fluxes (López-Gómez et al., 2012). Dominant palaeocurrent trends in the E Iberian Ranges point $95^{\circ}-150^{\circ}$ in the fluvial systems and $195^{\circ}-270^{\circ}$ in the aeolian systems. In the Catalan Ranges, dominant palaeocurrents in the fluvial systems point $130^{\circ}-185^{\circ}$, and are bidirectional $75^{\circ}-120^{\circ}$ and $235^{\circ}-285^{\circ}$ in the aeolian systems. In the E Pyrenees, dominating palaeocurrents trend $275^{\circ}-320^{\circ}$.

The upper part of the sedimentary cycle is not completely represented in the $S$ Iberian Ranges and, as stated above, only records its four youngest subunits (Ems-3, Ems-4, Ems-5 and Ems-6) in the Cedrillas-Corbalán section, and is even less detectable in the other sections, with a minimum in the Río Mayor section, where this formation was not deposited (Fig. 5). These four subunits are composed of fine sediments with intercalated sandstone levels (Figs. 3b, 8f) that become abundant in Ems-5. They mostly represent sandy braided $(\mathrm{SB}, \mathrm{CH})$ fluvial systems crossing huge floodplain $(\mathrm{FF})$ areas where soils developed (Fig. 9B) (Arche and López-Gómez, 2005) and isolated coal 
seems in the Castellar N’Hug area (Fig. 5). Some small aeolian dune systems (E1) developed intercalated in the fine deposits in the upper (Ems-6) Torre de Las Arcas Peñarroyas section, while some sandy meandering (LA) fluvial systems developed in the lower part of the same section (Ems-4). The middle portion of this section (Ems-5), however, represents the reactivation of the whole sedimentary system, with a record reduced in fine deposits and an increase in migrating channels and bar development (Fig. 9C) (Borruel-Abadía et al., 2014). Punctually, some aeolian reworking is observed in the fluvial systems of the Torre de las Arcas-Peñarroyas section, in subunit Ems-5.

\subsection{Mineralogy}

Our mineralogical composition study focuses on the Iberian and Catalan Ranges, as there are no data available on the mineral composition of the Triassic units in the selected area of the Pyrenees. In the Iberian Ranges, the mineralogical composition of the Cañizar and Eslida Fms. was firstly described by Alonso-Azcárate et al. (1997) in a general study, and completed in a more detailed study by Galán-Abellán et al. (2013b). subarkoses, with quartz, K-feldspar, lithic fragments of slates and phyllites, detrital mica, and accessory phases like rutile, zircon, ilmenite, monazite, apatite, tourmaline and, less frequently, xenotime. The matrix includes illite, hematite and less kaolinite in samples from the eastern sector of the basin, where it is extensively replaced by dickite (Martín-Martín et al., 2007). No primary porosity has been detected, and secondary porosity is filled with kaolinite, quartz, illite and iron oxide cements. In addition, samples from both units contain strontium-rich aluminium phosphate sulphate minerals (APS minerals). However, these phases are more abundant in the basal part of the 
353 Cañizar Fm., where they commonly replace lithic fragments. In samples from the Eslida

354 Fm., these APS minerals occur as tiny $(>3 \mu \mathrm{m})$ disseminated pseudocubic crystals.

355 Textural relationships strongly suggest that APS minerals are early diagenetic in origin,

356 and precipitated shortly after sedimentation, most probably under the influence of acidic

357 meteoric waters (Galán-Abellán et al., 2013b).

358

359

As mentioned before, the Cañizar Fm. is almost exclusively formed by sandstones. On the other hand, the Eslida Fm. includes mudstone and siltstone layers intercalated with sandstones. A remarkable feature of the Eslida Fm. is the local occurrence of carbonate (formed by dolomite or calcite) concretions in some palaeosols within these fine layers. Clay minerals in the mudstones are mainly illite, with minor amounts of pyrophyllite or kaolinite (the latter replaced by dickite), which are more abundant in the eastern sections. The illite crystallinity (IC) data indicate that most sections in the Iberian Ranges reached deep diagenetic conditions $\left(0.44^{\circ}\right.$ to $075^{\circ} \Delta 2 \Theta$; Benito et al., 2005), in agreement with the illite and dickitized kaolinite assemblage. However, the presence of pyrophyllite and lower IC data $\left(0.41\right.$ to $\left.0.28^{\circ} \Delta 2 \theta\right)$ in some sections (those showing the maximum thickness of the Eslida Fm.) are indicative of very low grade metamorphism (Alonso-Azcárate et al., 1997; Benito et al., 2005).

A preliminary approach to the mineralogical composition of the Early-Middle Triassic rocks of the Catalan Ranges was performed by Galán-Abellán (2011) in the 374 Eramprunyà unit (ES) and Aragall unit (ASM) in the central sector, and in the El Figarò unit (FMS) in the northern sector (Fig. 2). Mineral assemblages are rather similar to those found in the Iberian Ranges, and include quartz, hematite, illite and kaolinite, and 
377 minor amounts of feldspar. Dolomite and calcite rarely occur in the ES, but are frequent 378 in samples from both the ASM and FMS units. APS minerals are also found as 379 accessory phases in some samples. Sandstones and siltstones in the Catalan Ranges 380 show a lower degree of diagenesis, as revealed by IC data. Late diagenetic processes 381 promoted the development of secondary porosity, subsequently cemented by carbonate 382 (calcite and dolomite), which obliterated the original mineral assemblage. very low metamorphic conditions, these mineral assemblages cannot be directly used to decipher the palaeoclimatic conditions that prevailed during the sedimentation of these units. However, as will be discussed later, variations in clay mineral formation is related to chemical weathering intensification, a process dependent on atmospheric temperatures (Velde and Meunier, 2008).

\section{Palaeobotany}

Anisian Triassic plant remains have been recovered in both the Iberian and Catalan Ranges. In the Pyrenean Ranges, palynomorph assemblages have been only reported for the Buntsandstein facies (Broutin et al., 1988; Calvet et al., 1993; Díez, 2000; Díez et al., 2005), indicating an Anisian age. Studies of these records have been scarce but some include a detailed compilation of prior references and provide tentative palaeoenvironmental reconstructions. In the eastern Pyrenees only the palynomorph assemblages previously mentioned and some undetermined flora fragments have been found to date. 
Although without specifying a precise stratigraphic or geographic position,

401

402

403

404

405

406

407

408

409

410

411

412

413

414

415

416

417

Schmidt (1937, in Dobruskina, 1994), describe a Triassic macroflora in the S Iberian Ranges, identifying Pleuromeia sternbergii (Münster) Corda.

There are no reports of macrofloral remains in the Cañizar Fm. (Figs. 5 and 9A).

The only remains in the units of the Iberian Ranges examined appear in the Eslida Fm.

In this unit, different floral associations indicate an upward decrease in floral diversity.

In the Eslida Fm., floral associations types can be distinguished depending on the plant remains found. The first, found in subunits Ems-3 and Ems-4 (Fig. 9B), features a macroflora composed of riparian vegetation including semiarborescent lycophytes (Pleuromeia), sphenophytes (at least Equisetites, perhaps also Neocalamites) and more hygrophytic conifers, such as Pelourdea (Borruel-Abadía et al., 2014) (Fig. 10a, b, c). The vegetation of the lowlands is characterized by drier conditions, where various species of arboreous conifers developed, such as Voltzia, and shrubby ones such as Albertia. The possible hinterland vegetation consists of conifers along with shrubs (Albertia) and trees (Voltzia) (Fig. 10d). These associations are laterally arranged but also appear vertically alternating, probably indicating the alternation of drier and more humid conditions, possibly in a seasonal climate, but also indicating a position more or less distal to channels (Borruel-Abadía et al., 2014).

In subunit Ems-5 of the Eslida Fm., where $\mathrm{CH}$ and SB architectural elements dominate, large indeterminate fragments of putative conifers have been found, probably as a result of their greater resistance to transport (Borruel-Abadía et al., 2014) (Fig. 9C). However, this could also be the outcome of a more sparse vegetation that does not protect soils from erosion. Besides, the presence of conifers only could indicate a shift to more arid conditions, taphonomic selection or a combination of both. 
In subunit Ems-6 of the Eslida Fm., only a Pleuromeia fragment and speciments

of bad preserved Peltaspermum, maybe part of a fern with seeds, have been identified.

This is striking because in subunits Ems-3 and Ems-4 showing similar sedimentation and preservation characteristics, a larger number of specimens have been discovered. This could be due to arid conditions near inland sabkhas inferred from sedimentologic criteria (Borruel-Abadía et al., 2014).

The only pollen assemblage described in the Eslida Fm. consists of conifers, ferns and seed ferns, and contains Podocarpeaepollenite, Minotosaccus, Platysaccus, Succintisporites and Cristatitriletes (Boulouard and Viallard, 1982).

In the N Iberian Ranges, in equivalent stratigraphic positions, Díez et al. (1996) and Díez (2000) described a similar Anisian association composed of Darneya sp., Darneya peltata, Equisetites sp., Neocalamites sp., Neocalamites cf. carrerei, Willsiostrobus sp., Willsiostrobus rhomboidalis, Pelourdea vogesiaca, Albertia sp., Voltzia sp., Voltzia heterophylla and Voltzia walchiaeformis. In this latter area, two palynomorph assemblages have been described in the Cálcena Fm. (Arribas, 1984) in a possible stratigraphic location equivalent to the upper part of the Eslida Fm., that mainly contains conifers and ferns (Alisporites, Chordasporites, Triadispora, Verrucosisporites and Volziaceaesporites) (Díez et al., 2007).

Palaeoenvironmental reconstructions of these associations point to a riparian vegetation comprising plants living near the water body (permanent floodplain ponds or river) subjected to periodical floods. The vegetation around the water bodies is composed of sphenophytes (Equisetites and Neocalamites) and hygrophytic conifers such as Pelourdea (see also Kustatscher et al., 2014). Further from the water body, lowland vegetation is characterized by drier conditions, and includes various species of 
conifers such as Voltzia, Albertia. Possible hinterland vegetation (permanent ground or seasonally dry) comprises conifers (Voltzia, Albertia, Willsiostrobus and Darneya).

\subsection{Catalan Coastal Ranges}

In the Catalan Ranges, the first macrofloral remains appear in the so-called "Lower Buntsandstein", and take the form of a putative Pleuromeia, located in the upper part of the Eramprunyà Unit, which is equivalent to the top of the Cañizar Fm. (Galán-Abellán et al., 2013a).

In the "Upper Buntsandstein", in green shales with malachite, Almera (1909) described an association composed of remains of Albertia sp., Calamites sp., Voltzia heterophylla and Pecopteris sulziana. Two similar bands with macrofloral remains were reported by Calzada (1987). The lower one only contains Equisetites sp. and the higher one Aethophyllum sp. and Equisetites cf. mougeotti. Original lithostratigraphic descriptions of the levels where the samples were obtained point to the El Figarò Unit, in a stratigraphically equivalent level towards the top of the Eslida Fm. (Galán-Abellán et al., 2013a).

In the Catalan Ranges (El Figarò Unit), hygrophytic taxa that grew in the wetter areas around ponds and along river banks can also be observed such as sphenophytes (Equisetites and Calamites) and ferns (Pecopteris sulziana). The vegetation of the lowlands is characterized by species of arboreous conifers, such as Voltzia and Aethophyllum, and shrubby species, such as Albertia, as well as ferns in the understory (Aethophyllum and Pecopteris).

Macrofloral remains found in the Son Serralta Fm. of Majorca (Calafat-Colom, 1988; Álvarez-Ramis et al., 1995) are similar to the ones described in the El Figarò Unit 
471 of the Catalan Ranges, and consist of Aethophyllum stipulare, Albertia sp., Anomopteris

472 mougeotti, Endolepis sp., Equisetites sp., Equisetites mougeotii, Neuropteridium sp., 473 Schizoneura-Echinostachys paradoxa, Voltzia heterophylla Brongniart, Voltzia

474 walchiaeformis, Willsiostrobus hexasacciphorus, Willsiostrobus sp. and Pelourdea cf. 475 vogesiaca. This assemblage is attributed to the middle Anisian in view of the 476 palynological analysis published by Ramos and Doubinger (1989).

In NW Sardinia, inside a whitish horizon in the Cala Viola sandstones, Pecorini 478 (1962) found estherias and plant remains (Equisetum cf. mougeotii), and attributed such 479 a formation to the Lower Triassic. Two distinct palynomorph associations of 480 (?)Scythian-early Anisian and late Anisian age from the subsurface are reported in 481 comparable deposits (Pittau and Del Rio, 2002).

482

\section{Palaeosols}

484

Our palaeosol study mainly focused on some profiles of the Eslida Fm., in the 485 Gátova stratigraphic section of the Iberian Ranges (Fig. 11). Only levels showing root traces, soil structure, and soil horizons were considered paleosols (Retallack, 1988, 2005). These palaeosols have been differentiated and classified into a field scheme of pedotypes using established criteria (Retallack, 1997). The USDA Soil Taxonomy system (Soil Survey Staff, 1999) was used to define horizons using letters (such as A, $\mathrm{Bt}$ and $\mathrm{Bk}$ ) and to designate diagnostic horizons. The classification of Machette (1985) was used for the state of carbonate accumulation, and the degree of development of the palaeosol was estimated using the scale of Retallack (1988). 
The first evidence of pedogenesis was observed at the top of subunit Ems-3 and base of subunit Ems-4, in silty red floodplain facies. Vertical root traces and a thick (5$10 \mathrm{~mm}$ ) platy structure are related to the thin ochric epipedons and incipient subsurface clayey horizons of pedotype Gat-A (Fig. 11A). Root traces are scarce, short $(5-10 \mathrm{~cm})$ and preserved by infills of red or green clay. Dispersed powdery carbonate and carbonate nodules (stage I-II, Machette, 1985) occur in the subsurface clayey horizons, only a few centimetres beneath the soil surface $(5-10 \mathrm{~cm})$, but this calcareous level does not constitute a calcic $(\mathrm{Bk})$ horizon. Nodules are horizontally elongated $(2-5 \mathrm{~cm})$ but thin $(0.5-1 \mathrm{~cm})$ and show a lenticular shape. The shallow scarce root traces, the only slightly altered bedding, and short distance to the carbonate disc-shaped nodules are indicative of a sparse vegetation that probably developed under dry conditions for most of the year (Retallack, 2005). These palaeosols represent weakly developed silty to sandy Entisols of flat land surfaces, which were not frequently flooded and developed under arid climates.

The upper part of subunit E4 displays palaeosols at carbonate accumulation stage IIIII in the floodplain facies (Machette, 1985). These moderately developed silty red palaeosols are characterized by a partially eroded Bt clayey horizon, from which root traces emanate downwards into a Bk calcic horizon of slightly coalescing carbonate nodules measuring 0.5-2 cm (pedotype Gat-B; Fig. 11B). Columnar and subangular blocky structures are observed in the Bt horizon, which is also burrowed by several channels of roots of small size (up to $12 \mathrm{~cm}$ in length). Bk horizon thickness is up to 20

$514 \mathrm{~cm}$ and entire profiles are generally 30 to $40 \mathrm{~cm}$. The Gat-B pedotype was classified as an Inceptisol (Soil Survey Staff, 1999). 
Under arid climates, thicker Bk horizons are usually interpreted as indicative of a longer time of pedogenic development (Gile et al., 1966). However, in non-extreme arid 518 climates, thicker Bk horizons are the result of seasonal variations in soil wetting depth (Retallack, 2005) and greater plant activity (Alonso-Zarza et al., 2003). As the thickness of the $\mathrm{Bk}$ horizon does not exceed $30 \mathrm{~cm}$, there is no evident seasonal variation in rainfall (Retallack, 2005). However, the greater presence of root traces suggests better conditions for plant growth, and, thus, this part of subunit Ems-4 was deposited under conditions of slightly higher mean annual rainfall than for the Ems-3 - Ems-4 transition.

The base of the Ems-5 subunit features palaeosols developed on abandoned channel deposits of the fluvial system (pedotype Gat-C; Fig. 11C). These palaeosols are characterized by poor alteration of the bedding as long root traces penetrate channelized sand bars. The most common type is composed of a single vertical root up to $1.5 \mathrm{~m}$ long and $4 \mathrm{~cm}$ thick, with rootlets radiating downwards another $20-30 \mathrm{~cm}$ from the lower part of the main root (Fig. 11D). This pattern is similar to modern adventitious prop roots that support trees in soft sandy sediments. Also observed were dispersed small lateral roots and main roots or taproots up to $45 \mathrm{~cm}$ long and $5 \mathrm{~cm}$ thick, with little branching,

532 profuse hair roots, and ending in rounded tap roots (Fig. 11E). Due to poor alteration of 533 the parent material, the sandy Gat-C pedotype was classified as a Fluvent in the order Entisol (Soil Survey Staff, 1999), also possibly indicating high erosion rates and an arid climate. In their study of the palaeoflora of the Eslida Fm., Borruel-Abadía et al. (2014) found no lycophytes, sphenophytes and hygrophytic conifers in this subunit. As only conifer remains were found, these authors proposed a drier climate (Borruel-Abadía et al., 2014). However, in spite of this dry climate, the growing well-sized trees were possible in some areas (Fig. 9C). 
The E6 subunit is characterized by the presence of silty palaeosols with profuse drab-haloed root traces (Fig. 11). A light red horizon with fine subangular blocky structure lies on top of a clayey Bt horizon with a dense pattern of fibrous root systems.

543 Very few dispersed carbonate nodules were observed at a depth of $35 \mathrm{~cm}$ from the 544 profile top. These weakly developed palaeosols do not reach the criteria for Alfisols and 545 were classified as Inceptisols. Drab-haloed root traces are usually interpreted as 546 chemical reduction related to anaerobic bacterial activity in stagnant water (Retallack, 547 1997). However, the Gat-D pedotype lacks a gleyed superficial horizon and the drab548 haloed root traces are probably the outcome of anaerobic decay in the rhizospere and 549 other areas after burial. Observed features of the Gat-D pedotype (Fig. 11E) point to 550 oxidizing dry soils though periodic waterlogging cannot be ruled out.

552 described by Marzo et al. (1974) and Marzo (1980) in the middle part of the El Figaró 553 unit. This may appear in floodplains or close to meandering channels and was 554 interpreted as early mature caliche resulting from short subaerial exposures in semiarid conditions.

\section{Discussion}

\subsection{Climate variations}

Through a detailed study of the sedimentary characteristics and fossil contents of selected lithostratigraphical units of the S Iberian Ranges, E Pyrenees and Catalan

560 Ranges, we were able to identify different phases of climate installation and 561 development during the Early-Middle Triassic. Despite the fact that these basins were hundreds of kilometres apart and adopted their own characteristics during their refill, 
563

564

565

566

567

568

569

570

571

572

573

574

575

576

577

578

579

580

581

582

583

584

585

common sedimentary features appear in the sedimentary record of the time-interval examined.

Some of these features, described above and shown in figure 5, are provided in figure 12 as climate indicators. The more remarkable indicators detected in most of the studied sections are here considered representative of the entire study area. Punctuate sedimentary characteristics of some sections are used as regional or local climate indicators.

The first sedimentary record of the basins examined starts during the late Smithian and continues in the Spathian until its interruption at the beginning of the Anisian (López-Gómez et al., 2012; Galán-Abellán et al., 2013a; Ronchi et al., 2014). Although it seems there were no clear humid nor subhumid climate stages during that time, remarkable arid and semi-arid climate period alternations were observed. Three clear arid periods, usually well represented by aeolian dune field sedimentation, developed at the end Smithian, transition to the Spathian, middle Spathian and transition to the Aegean (Fig. 12). In addition, several authors (De la Horra et al., 2005, 2008, 2011; Durand, 2006, 2008; Bourquin et al., 2007; 2011; Cassinis et al. 2007) suggest a (hyper)-arid period during the first of these time-intervals when plant remains are absent (Durand, 2006, 2008; Bourquin et al., 2007, 2011). The durations of these three arid phases are probably decreasing from the oldest to the youngest, and thus, involved the development of major semi-arid stages. As the studied Early Triassic time-interval represents about 1.5 m.a., each of the three alternating arid to semi-arid intervals would be shorter than 0.4 m.a. Semi-arid intercalated stages were represented by developing braided fluvial systems in all the basins. In some cases, these depositional systems were 
586

587

588

589

590

591

592

593

594

595

596

597

598

599

600

601

602

603

604

605

606

607

608

609

laterally interconnected with the development of small aeolian field dunes (López-

Gómez et al., 2012).

The presence of major boundary surface 5 (mbs5) in the different sections of the study basins (Fig. 12), its age and characteristics, was considered as an important regional event (López-Gómez et al., 2012; Galán-Abellán et al., 2013a), probably related to the Hardegsen unconformity described in Western Europe (e.g. Aigner and Bachmann, 1992; Bourquin et al., 2007, 2009) and linked to stages of tectonic activity at the end of the Early Triassic. In our basins, this regional change is also reflected by low angle unconformities in sections near the basin border, and coincides with a more humid stage after an arid episode and the start of life recovery after the Permian-Triassic crisis (López-Gómez et al., 2012).

Despite the development of these generalized and laterally continued climate stages, some areas in the E. Iberian Ranges (Gátova section) and E Pyrenees (Castellar N'Hug) hardly show aeolian sediments. On the contrary, in the southern Catalan Basin (S. Gregori section), almost the whole sedimentary record consists of aeolian sediments. These punctate geographical differences, as detailed below, point to a dishomogeneous climate distribution and to climate control.

After a sedimentary interruption and slight erosion event during the Aegean, a new cycle of sedimentation started at the beginning of the Bithynian (Fig. 12). This new cycle, represented by the Eslida Fm., the "upper Buntsandstein" or El Figarò Unit in the Iberian Ranges, E. Pyrenees and Catalan Ranges, respectively, was related to tectonic reactivation and new re-organization and orientation of the rift basins in Iberia (Arche and López-Gómez, 1996, 2005). Mudstones and siltstones represent the main lithological change compared to the previous cycle. However tectonics was not the only 
reason for these lithological variations, and rather, a change in climate allowed for the sedimentation of different deposits and the emergence of new alluvial sedimentary 612 styles.

The development of extensive meandering fluvial systems, and the appearance of sphenophytes, conifers and isolated coal levels in subunits Ems-3 and Ems-4 suggests the presence of the two short humid phases in the middle Bithynian (Fig. 12). These characteristics were widely developed during these stages in different areas of the 617 three study basins. The two humid stages, however, only represented interruptions of a more prolonged period of alternating subhumid and semi-arid stages that lasted until the end of the Bithynian and continued into the beginning of the Pelsonian, when sedimentation of the Röt facies (Marines Fm.) reflects the transition to the first Tethys sea incursion (Muschelkalk facies) in Iberia (Escudero-Mozo et al., 2014). The proximity in time of these two humid stages could mean their interpretation as a single humid interval in some sections. presence, on the appearance of hinterland vegetation of conifers (Voltzia, Albertia, Willsiostrobus and Darneya) and on soil development as the presence of thicker Bk horizons in non-extreme arid conditions, subhumid stages would consist here of seasonal precipitation, whereby extreme temperatures and rainfall were probably not persistent plant development, soil growth and permanent or semi-permanent flows in river systems are described. 
633 Arcas-Peñarroyas section), was also marked by the presence of xerophytic vegetation, and presence of unconfined braided fluvial systems.

635

636

637

\subsection{Palaeoclimatic and palaeogeographic implications}

The simplistic hot-house scenario for the Early-Middle Triassic, evoking strong monsoon circulation and seasonal rain without zonal patterns (Kiehl and Shields, 2005; Preto et al., 2010), has been recently modified by the incorporation of detailed regional data to define a more complete evolution model for this period of time (Romano et al., 2013; Sun et al., 2012).

Although temperatures had risen rapidly during the end-Permian mass extinction, they reached exceptionally high values in the Early Triassic (Brayard et al., 2010). These high temperatures also experienced large abrupt changes such as that observed in the Smithian-Spathian transition of up to $40^{\circ}$ at the equator (Sun et al., 2012), which was probably the consequence of a carbon cycle disturbance caused by a sequence of large-scale $\mathrm{CO} 2$ injections from the Siberian Large Igneous Province (Payne et al., 2004; Galfetti et al., 2007; Romano et al., 2013).

The latest Smithian was a time of warm and equable climate, expressed as an almost flat pole to equator sea surface temperature gradient, compared to the steep gradient at the beginning of the Spathian, indicating clear latitudinally differentiated climate conditions (Kidder and Worsley, 2004; Preto et al., 2010) inducing a synchronous major change in both terrestrial and marine ecosystems (Galfetti et al., 2007). This change was observed in the present study area, where aeolian-fluvial sedimentation at the end of the Smithian underwent a sudden change towards pure fluvial sedimentation of a semi-arid nature at the beginning of the Spathian (Fig. 12) (Bourquin et al., 2011; López-Gómez et al., 2012; Galán-Abellán et al., 2013a). 
657 However, the new fluvial sedimentation trend that started at the beginning of the 658 Spathian in these areas was not permanent as new arid conditions once again arose.

These high temperature values together with their changing character, thwarted ecosystem recovery during the Early Triassic (Retallack et al., 2011; Sun et al., 2012). In the Iberian Plate, no fossil record is known until the late Spathian (López-Gómez et al., 2012; Galán-Abellán et al., 2013a; Borruel-Abadía et al., 2014) (Fig. 12), clearly coinciding with the first recognized humid and cooler stage in the Triassic rocks of this area, about 5 m.a. after the PTB. A taphonomic filter is initially discarded as this absence includes plants, tetrapods, insects, soils and bioturbation. Until this time, arid 666 and semi-arid conditions were mainly the dominant environmental conditions represented in all the study basins, with a remarkable late Smithian arid stage followed by a cooler period in the earliest Spathian. This latter stage may coincide with the marine cooling event related to strong recovery of many clades described by Brayard et al. (2009), Romano et al. (2013), Sun et al. (2012, 2015) and Chen and Benton (2012).

A humid climate stage can enhance subaerial weathering with consequences on 672 ocean nutrient fluxes (Payne et al., 2004; Twitchett, 2007; Algeo and Twitchett, 2010; 673 Benton and Newell, 2014). Higher ocean nutrient levels may initially increase 674 productivity, which indicates continent-ocean connections (Algeo et al., 2011). These latter authors propose a chemical weathering stage by the late Spathian accounting for the marine productivity increase. This stage fits in well with the one postulated for the

677 Iberian plate and its possible extension in Western Europe. Its association with the 678 recovery of continental life described here reinforces the idea of continental-marine 679 connections described by Algeo et al. (2011). 

corridors, as could have happened in the Iberian Plate. These new routes appearing in the megacontinent would promote rifting connections and alluvial fluxes, incorporating more oxygenated waters to the sea and contributing to life recovery. Diedrich (2008) described millions of reptile tracks during the Early-Middle Triassic as a consequence of fauna migration across corridors and bridges in Central Europe. In the Iberian and Catalan Ranges, the first reptile tracks were localized in the uppermost Cañizar Fm., latest Spathian (Gand et al., 2010) (Fig. 12), just after the cited unconformity, and were lacertoid three digit prints of Rhynchosauroides. Above these levels, and already in the Anisian (mainly Bithynian), footprints of specimens of both Lacertoïd and Crocodiloïd groups are common (Gand et al., 2010; Fortuny, 2011) and coincide with the appearance of the first Mesozoic (triadotypomorphan) insect in Spain, rubra sp. nov. (Béthoux et al., 2009).

Plant fossils have been used for climate reconstruction based on their ecology inferred from living relatives. Climate is commonly recorded in the sedimentary record by vegetation, and the effects this vegetation has on sediment erodibility, sediment yield and channel style, among others (Miall, 1996). The early Anisian floral associations of both the Iberian and Catalan Ranges are similar and mainly composed of conifers and sphenophytes. These floral associations resemble that of the "Grès à Voltzia" Fm. of north-eastern France (Grauvogel-Stamm, 1978). It is likely that the plants of the "Grès à Voltzia" that already appear in the Pleuromeia flora (Fuchs et al., 1991; Mader, 1990; Grauvogel-Stamm, 1999) escaped the end-Permian life crisis in extrabasin refugia. Pleuromeia-like fossils reveal that Pleuromeia may have survived into the Anisian in

703 the Iberian Ranges. Moreover, as shown by Grauvogel-Stamm and Ash (2005), 
lycophytes played an important role in the recovery of land plants in the Early Triassic and could have adapted to unfavourable arid conditions. The replacement of the Pleuromeia flora by conifer-dominated or Voltzia flora may be the consequence of a change in climate and growth conditions, enabling the Voltzia flora to invade basin lowlands (Grauvogel-Stamm and Ash, 2005).

The plant associations of the Iberian and Catalan Ranges point to alternating seasonally dry and more humid conditions (Borruel-Abadía et al., 2014). Riparian vegetation, that is, plants living near the water body (permanent floodplain ponds or river), was exposed to periodical flooding. The vegetation around the water bodies was composed of semiarborescent lycophytes, sphenophytes and more hygrophytic conifers. Further from the water bodies, lowland vegetation was characterized by drier conditions, where several species of arboreous and shrubby conifers, and ferns grew. Clearings were colonized by ferns mixed with some conifers, and the possible hinterland vegetation (permanent ground or seasonally dry) consisted of conifers with shrubs and trees. The first more humid short stage, recognized in the early Anisian (Bithynian) in both the Iberian and Catalan Ranges sections, appears in subunits Ems-3 and Ems-4 related to a riparian-dominated vegetation.

Such alternations of dry and more humid conditions shown by the vertical distribution of early Anisian plants in the sections examined, fits in well with changes in river channel style in the same units described by Arche and López-Gómez (2005). Further, Borruel-Abadía et al. (2014) linked fossil plants to different fluvial architectural elements depending on the hygrophytic to semi-arid xerophytic deposition of the Eslida Fm. A second more humid early Anisian (Bithynian) short stage was observed in the Ems-4 subunit of this formation in the Iberian Ranges related to 
superimposed meandering fluvial systems and associated riparian vegetation. In similar studies, Smith (1995) interpreted the facies transition in the Permian-Triassic Karoo Basin as a change in fluvial style from meandering to low sinuosity channels with general drying of floodplain habitats. Davis and Gibling (2010) described a sharp increase in the abundance of meandering rivers in the middle Palaeozoic due to colonization of terrestrial environments by vegetation. The soils of the sections here examined formed in the floodplains during long sedimentation pauses.

Although they are poorly developed, pedotype characteristics also revealed clearly alternating climate conditions. According to the information obtained from the Eslida palaeosols, a general trend of seasonal, alternating drier and slightly humid or semi-arid climate conditions was inferred. The unit is represented by poorly developed soils with shallow calcareous horizons in the lower part of the Eslida Fm. indicative of arid conditions (pedotypes Gat-A), which moved towards slightly higher mean annual palaeoprecipitation (pedotype Gat-B) and possibly better conditions for tree growth (Gat-C). The top of the unit is marked by pedotype Gat-D, with a dense and laterally continuous pattern of fibrous root systems, indicating a well-developed vegetative cover formed under a more seasonally semi-arid climate. Despite such different climate conditions, however, it is difficult to identify clear monsoon characteristics in the sedimentary record, as they can be easily confused with other seasonal effects (Miall, 1996).

Faster soil reaction rates in the Anisian cycle of sedimentation in response to warmer temperatures probably intensified chemical weathering (e.g. Korte et al., 2005) providing clay minerals as crucial data for inferring palaeoclimates. This type of mineralogy has been frequently used to detect changes in the climate conditions 
752 prevailing during their sedimentation (Righi and Meunier, 1995; Hong et al., 2007;

753 Wang et al., 2013). However, diagenetic alteration and source rock composition should 754 always be considered (Chamley, 1989; Hillier, 1995; Yakimenco et al., 2000). The 755 mineral assemblages of the Cañizar and Eslida Fms. in the Iberian Ranges can hardly be 756 used for this purpose, as the original clay mineralogy has been largely obliterated by 757 deep diagenetic and even very low grade metamorphic processes, as evidenced by the presence of dickite and pyrophyllite, respectively, and by illite crystallinity data. In the Catalan Ranges, the generation of secondary porosity and subsequent carbonate cement precipitation during late diagenesis also make it difficult to recognize the original mineral assemblage. In addition, most clay minerals in these units are probably detrital (Alonso-Azcárate et al., 1997) even in the clay fraction, and it is hard to distinguish between authigenic and detrital particles. Consequently, the mineral cannot be linked to a specific climate. However, the presence of pyrophyllite or dickite in samples from both units can be regarded as indirect evidence of the presence of kaolinite in the original clay mineral assemblage, which would have been transformed during 767 diagenesis or very low grade metamorphism. According to Martín-Martín et al. (2007) and Galán-Abellán et al. (2013b), kaolinite formed by weathering of detrital micas and to a lesser extent of K-feldspar, and this alteration implies relatively humid conditions and low $\mathrm{pH}$ values to allow for the hydrolysis of these phases. These low $\mathrm{pH}$ values, probably the outcome of higher levels of atmospheric $\mathrm{CO}_{2}$ along with volcanic $\mathrm{SO}_{2}$ 772 release (Wignall, 2007; Self et al., 2008), are indicated by the presence of APS minerals 773 in both the Cañizar and the Eslida Fms. (Galán-Abellán et al., 2013b). Indeed, a low pH could have been an additional environmental stressor for continental biota. 

hemisphere, facing the Tethys between $10^{\circ} \mathrm{N}$ and $14^{\circ} \mathrm{N}$ (Dinarés-Turell et al., 2005; Bourquin et al., 2011; Domeier et al., 2012). Interestingly, the latitudinal position of Iberia during the Early Triassic was one of generally wetter conditions than most of the rest of Europe (Fig. 13). During this time, river systems flowed to the sea, but punctually these systems were interrupted by aeolian dune fields (Galán-Abellán et al., 2013a). These interruptions, nevertheless, diminished in time and space during the beginning of the Anisian, when alternating wet-dry conditions prevailed. from its pronounced orography. The Iberian plate, being part of the ancient boundary between Gondwana and Laurasia during the assembly of Pangea, experienced significant deformation identified in part of the highly curved Variscan belt of southwestern Europe (Weil et al., 2001; Martínez-Catalán, 2011). Such intense deformation led to the development of mountain belts continuing well into the Permian and even Early-Middle Triassic (López-Gómez et al., 2012). Mountain orography induces atmospheric circulation changes. Fluteau et al. (2001) compared different palaeogeographic scenarios in the Late Permian by testing palaeo-elevations through sensitivity experiments. These authors noted a substantial increase in aridity in the elevated Variscan belt that contributed to the development of aeolian facies and xeromorphic vegetation. These latter authors also estimated an altitude between 2000 $3000 \mathrm{~m}$ in southern Europe for the Late Permian, elevations that persisted until the 
800 Triassic: the Ateca-Montalbán High (AMH), Ebro High (EH) and Girona High (GH)

801 (Fig. 13). These elevated areas and dominant $\mathrm{E}$ and $\mathrm{NE}$ winds led to the development of 802 the alluvial systems and aeolian dune fields represented by the Cañizar Fm. in the 803 Iberian Ranges (López-Gómez et al., 2012), Eramprunyà Unit in the Catalan Ranges 804 (Galán-Abellán et al., 2013a) or the "Upper Buntsandstein" in the E Pyrenees Ranges. 805 These palaeohighs, differing in their palaeogeographic morphology, size and 806 orientation, allowed for the development of a vast dune field area enclosed between the

807 Ebro and the Ateca-Montalbán Highs in the middle Spathian (Fig. 13). Fluvial systems were simultaneously surrounding these dune fields across narrow corridors, and most probably they never reached the Tethys developing an endorreheic system. South of the Ateca-Montalbán High, however, practically no aeolian sands were deposited except in punctuate levels of isolated areas (Galán-Abellán et al., 2013a). 12). During the latter intervals, fluvial drainage was more extensive and most of dune field areas disappeared or were reduced to smaller areas (Fig. 12). In the late Spathian and early Anisian, more humid periods appeared and plants and animals started to colonize.

The Ateca-Montalbán High was a geographical boundary with the more humid areas towards the equator, in the E Argana Basin (Morocco). Here, no aeolian sediments were recorded during the Early Triassic (Tourani et al., 2010; Klein et al., 2010). These climate boundaries are consistent with mean annual precipitation simulations by Bourquin et al. (2007), indicating more than double precipitation in Argana with respect to the Iberian Plate (from $<0.1 \mathrm{~mm} /$ day to $>1 \mathrm{~mm} /$ day) during the Olenekian. In 
contrast, more extensive arid areas than those of the Iberian plate developed during this time in Central and Southern Europe (Bourquin et al., 2009, 2011). Interestingly, the first tetrapod footprints in the Iberian Plate are recorded in the early Anisian (Fortuny, 2011) during a more humid period, probably as result of migrations from the still prevailing more arid conditions of central Europe.

As previously exposed, the causes driving the inferred climate changes during the Early Triassic have been broadly discussed by different authors, including those related to different volcanism pulses in Siberia. In the Iberian Plate, and probably in neighboring Western Europe areas, tectonics related to the Hardegsen event could have also reactivated already elevated areas. This new palaeogeographic scenario could allow the opening of corridors in land favoring the development and reactivation of drainage networks and the beginning a more humid episode at the end of the Spathian, also favored by the near equator latitudinal position of Iberia. These circumstances, humidity, corridors and more oxygenated waters would have contributed to the fauna and flora recovery in these basins at the end of the Early Triassic.

\section{Conclusions}

The continental rocks (Buntsandstein facies) and fossils of eastern Iberia's basins provide insight into the climate of the western Tethys domain during the Early-Middle Triassic. This study suggests climate variations for these near equator $\left(10^{\circ}-14^{\circ} \mathrm{N}\right)$ areas.

The Early Triassic was mainly dominated by alternating periods, normally shorter than 0.4 m.a., of arid to semi-arid climates. Two main arid periods marked by aeolian field dune development occurred at the end of the Smithian and middle of the Spathian. 
847 just after an unconformity related to the western European tectonically induced

848 Hardegsen event that could be related with the beginning of fauna and flora recovery in

849 the study basins. After another short arid period at the end of the Olenekian, the

850 beginning of the Anisian (Aegean) was marked by short periods of alternating arid and

851 semi-arid to subhumid intervals. The Bithynian and Pelsonian clearly represent a wetter

852 time, showing alternating semi-arid to subhumid intervals interrupted by two short

853 humid episodes in the late Bithynian but also a short isolated arid interval near the

854 Bithynian/Pelsonian boundary.

Climates in Iberia during this period of time were clearly conditioned by relict

Variscan. As a result, isolated internal climate zones separated by elevated areas appeared. South of the Ateca-Montalbán High, the generalized wetter climate during the

858 late Olenekian - early Anisian extended towards the equator to the present-day 859 Moroccan Meseta and Argana Basin.

\section{Acknowledgements} Mexico) and an anonymous reviewer for providing helpful recommendations to 863 improve this manuscript. This work was supported by a FPI predoctoral contract held 864 by V.B-A. and by project grant CGL2008-24408 awarded by the Spanish Ministry of 865 Economy and Competitiveness. This paper is also a contribution to the following research projects: "Sistemas Sedimentarios y Variabilidad Climática" (642853) of the

867 CSIC, and Basin Analysis (910429), and Palaeoclimatology and Global Change 868 (910198) of the Universidad Complutense de Madrid. Part of the macroflora 869 information was obtained with the collaboration of Evelyn Kustatcher and Carmen 
870 Díeguez and previously published in Borruel-Abadía et al. (2014). We thank A. Burton

871 for revising the English version of the manuscript.

\section{References}

873 Aigner, T., Bachmann, G.H., 1992. Sequence-stratigraphic framework of the German 874 Triassic. Sedimentary Geology 80, 115-135.

875 Algeo, T.J., Twichett, R.J., 2010. Anomalous Early Triassic sediment fluxes due to 876 elevated weathering rates and their biological consequences. Geology 38, 1023-1026.

877 Algeo, T. J., Chen, Z., Fraiser, M., Twitchett, R. J., 2011. Terrestrial-marine 878 teleconnections in the collapse and rebuilding of Early Triassic marine ecosystems. 879 Palaeogeography, Palaeoclimatology, Palaeoecology 308, 1-11.

880

881 Allen, J.P., Fielding, C.R. 2007. Sedimentology and stratigraphic architecture of the 882 Late Permian Betts Creek Beds, Queenland, Australia. Sedimentary Geology 202, 5-34.

884 Almera, L., 1909. Descobriment de una de les antigues floras triássicas. Bulletí de la 885 Institució Catalana d’Historia Natural 9, 11-14.

886 Alonso-Azcárate, J., Arche, A., Barrenechea, J.F., López-Gómez, J., Luque, J., Rodas, 887 M., 1997. Palaeogeographical significance of the clay minerals in the Permian and 888 Triassic sediments of the SE Iberian Ranges. Palaeogeography, Palaeoclimatology, 889 Palaeoecology 136, 309-330.

890 Alonso-Zarza, A.M., 2003. Palaeoenvironmental significance of palustrine carbonates 891 and calcretes in the geological record. Earth-Sci. Rev., 60, 261-298. 
892 Álvarez-Ramis, C., Fernández-Marrón, M. T., Calafat, F., 1995. Avance sobre la 893 megaflora triásica en facies germánica de Estellencs (sector noroccidental de la Sierra 894 de Tramuntana, Lallorca). Revista Española de Paleontología, número extraordinario 895 Homenaje al Doctor Guillermo Colom, 55-58.

896 Arche, A., López-Gómez, J., 1996. Origin of the Permian-Triassic Iberian Basin, 897 Central Spain. Tectonophysics 266, 433-464

898

Arche, A., López-Gómez, J., 1999. Subsidence rates and fluvial architecture of riftrelated Permian and Triassic alluvial sediments of the southeastern Iberian Range, Eastern Spain. In: Smith, N.D., Rodgers, N. (Eds.), Fluvial Sedimentology VI, Spec. Publ. Int. Ass. Sedimentology 28, pp. 283-384.

Arche, A., López-Gómez, J., 2005. Sudden changes in fluvial style across the PermianTriassic boundary in the Eastern Iberian Ranges, Spain: analysis of possible causes. Palaeogeography, Palaeoclimatology, Palaeoecology 229, 104-126.

Arribas, J., 1984. Sedimentología y diagénesis del Buntsandstein y Muschelkalk de la Rama Aragonesa de la Cordillera Ibérica (provincias de Soria y Zaragoza). PhD thesis, Universidad Complutense, Madrid. Unpublished

Baucon A., Ronchi A., Felletti F., Neto de Carvalho, C., 2014. Evolution of Crustaceans at the edge of the end-Permian crisis: ichnonetwork analysis of the fluvial succession of Nurra (Permian-Triassic, Sardinia, Italy). Palaeogeography Palaeoclimatology Palaeoecology 410, 74-103.

Benton, M. J., 2003. When life nearly died. The greatest mass extinction of all Time. Thames \& Hudson, London, 336 p. 
Benton, M., Newell, A., 2014. Impacts of global warming on Permo-Triassic terrestrial ecosystems. Gondwana Research 25 (4), 1308-1337.

917

918

Bercovici, A., Díez, J. B., Broutin, J., Bourquin, S., Linol, B., Villanueva-Amadoz, U., López-Gómez, J., Durand, M., 2009. Paleobotanical aspects of the Upper Permian 920 (Thuringian) of Minorca (Balearic Islands, Spain): biostratigraphical, biogeographical and paleoclimatic implications. Rev. Paleobot. Palynol 158, 14-28.

922

923

Berner, R. A., 2002. Examination of hypotheses for the Permo-Triassic boundary 924 extinction by carbon cycle modeling. Proc. Natl. Acad. Sci. USA. 99, 4172-4177.

925

926

Best, J.L., Ashworth, P.J., Bristow, C.S., Roden, J., 2003. Three-dimensional 927 sedimentary architecture of a large, mid-channel sand braid bar, Jamuna River, Bangladesh. Journal of Sedimentary Research 73 (4), 516-530.

929

Béthoux, O., De La Horra, R., Benito, M. B., Barrenechea, J. M., Galán-Abellán, B., 931 López-Gómez, J., 2009. A new triadotypomorphan insect from the Anisian (Middle 932 Triassic), Buntsandstein facies, Spain. Journal of Iberian Geology 35 (2), 179-184.

934 Blodgett, R. H., Stanley, K.O., 1980. Stratification bedforms and discharge relations of 935 the Platte braided system, Nebraska. Journal of Sedimentary Petrology 50, 139-148. 
937 Borruel-Abadía, V., Galán-Abellán, A.B., Kustatscher, E., Diéguez, C., López-Gómez,

938 J., De la Horra, R., Barrenechea, J.F., Arche, A., 2014. Palaeoenvironmental 939 reconstruction of the early Anisian from sedimentology and plant remains in the SE

940 Iberian Range (E. Spain). Palaeogeography, Palaeoclimatology, Palaeoecology 414, $941 \quad 352-369$.

942 Boulouard, C., Viallard, P., 1982. Reduction or lacune du Trias inférieur la bordure 943 méditerrannée de la Chaine Ibérique: arguments palynologiques. Comptes Rendus de 944 l'Academie des Sciences de Paris 295, 115-123.

945

946 Bourquin, S., Bercovici, A., López-Gómez, J., Díez, J.B., Broutin, J., Ronchi., A., 947 Durand, M., Arche, A., Linol, B., Amour, F., 2011. The Permian-Triassic transition and 948 the onset of Mesozoic sedimentation at the northwestern peri-Tethyan domain scale: 949 Palaeogeographic maps and geodynamic implications. Palaeogeography, 950 Palaeoclimatology, Palaeoecology 299, 265-280.

951 Bourquin, S., Durand, M., Díez, J. B., Broutin, J., Fluteau, F., 2007. The Permian952 Triassic boundary and Lower Triassic sedimentation in the Western European Basins: 953 an overview. Journal of Iberian Geology 33, 221-236.

954 Bourquin, S., Guillocheau, F., Péron, S., 2009. Braided river within an arid alluvial 955 plain (example from the Early Triassic, western German Basin): criteria of recognition 956 and expression of stratigraphic cycles. Sedimentology 56, 2235-2264. 
958

959

960

961

962

963

964

965

966

967

968

969

970

971

972

973

974

975

976

977

978 Calvet, F., Solé de Porta, N., Salvany, J.M., 1993. Cronoestratigrafía (Palinología) del

979

980

Brayard, A., Escarguel, G., Bucher, H., Monnet, C., Brühwiller, T., Goudemand, N.,

Galfetti, T., Guex, J., 2009. Good genes and good luck: ammonoid diversity and the end Permian mass extinction. Science 325, 1118-1121.

Bristow, C.S., 1993. Sedimentary structures exposed in bar tops in the Brahamaputra River, Bangladesh. In: Best, J.L., Bristow, C.S. (Eds.), Braided Rivers. Geol. Soc. Lond. Spec Publ. 75, 277-289.

Brookfield, M.E., 1992. Eolian systems. In: Walker, R.G., James, N.P. (Eds.), Facies Models. Response to sea level change. Geological Association of Canada pp. 143-156.

Broutin, J., Doubinger, J., Gisbert, J., Satta-Pasini, S., 1988. Permières datations palynologiques dans les faciès Buntsandstein des Pyrénées catalanes espagnoles. Comptes Rendus de l'Academie des Sciences de Paris 2, 159-163.

Calafat-Colom, F.J., 1988. Estratigrafía y sedimentología de la litofacies Buntsandstein de Mallorca. PhD. Thesis. Barcelona University. 125 p. Unpublished

Calvet, F., Marzo, M., 1994. El Triásico de las Cordilleras Catalanas: Estratigrafía, sedimentología y análisis secuencial. In: A. Arche (Ed.), Conferencia de Estratigrafía y Paleogeografía de España. Cuenca. Field Trip Guide. 55p.

Triásico sudpirenaico y del Pirineo Vasco-Cantábrico. Acta Geologica Hispanica 28, $33-48$. 
981 Calzada, S., 1987. Niveles fosilíferos de la facies Buntsandstein (Trias) en el sector

982

983

984

985

986

987

988

989

990

991

992

993

994

995

996

997

998

999

1000

1001

1002

norte de los Catalánides. Cuadernos de Geología Ibérica 11, 256-271.

Cassinis G., Durand M., Ronchi A., 2003. Permian-Triassic continental sequences of northwest Sardinia and south Provence: stratigraphic correlations and palaeogeographic implications. In: Decandia, F.A., Cassinis, G. Spina, A. (Eds.), Late Palaeozoic to Early Mesozoic events of Mediterranean Europe, and additional regional reports. Spec. Proc. Int. Meeting, Siena, 2001. Boll. Soc. Geol. It., Spec. 2, 119-129.

Cassinis G., Durand M., Ronchi A., 2007. Remarks on the Permian and PermianTriassic boundary in central and eastern Lombardy (Southern Alps, Italy). Journal of Iberian Geology 33 (2), 133-142.

Cassinis, G., Perotti, C., Ronchi. A., 2012. Permian continental basins in the Southern Alps (Italy) and Peri-Mediterranean correlations. International Journal of Earth Sciences $101,129-150$.

Chen, Z. Q., Benton, M., 2012. The timing and pattern of biotic recovery following the end-Permian mass extinction. Nature geoscience 5, 375-383.

Davies, N.S., Gibling, M.R., 2010. Paleozoic vegetation and the Silurian-Devonian rise of fluvial lateral accretion sets. Geology $38,51-54$. 
1003

1004

1005

1006

1007

1008

1009

1010

1011

1012

1013

1014

1015

1016

1017

1018

1019

1020

1021

1022

1023

1024

1025

De la Horra, R., Benito, M.I., López-Gómez, J., Arche, A., Barrenechea, J.F., Luque, J., 2008. Palaeoenvironmental significance of Late Permian Paleosols in SE Iberian Ranges, Spain. Sedimentology 55, 1849-1873.

De la Horra, R., Galán-Abellán, B., López-Gómez, J., Sheldon, N.D., Barrenechea, J.F., Luque, J., Arche, A., Benito, M.I., 2012. Palaeoecological, palaeoenvironmental changes during the continental Middle-Late Permian transition at the SE Iberian Ranges, Spain. Global and Planetary Change 94-95, 46-61.

De la Horra, R., López-Gómez, J., Arche, A., 2005. Caracterización de la Unidad Conglomerados de Valdemeca en la transición Pérmico-Triásico de la Cordillera Ibérica centro-oriental. Geotemas 8, 141-145.

De Vicente, G., Vegas, R., Muñoz-Martín, A., Van Wees, J.D., Casa-Sainz, A., Sopeña, A., Sánchez-Moya, Y., Arche, A., López-Gómez, J., Olaiz, A., Fernández-Lozano, J., 2009. Oblique strain partioning and transpression on an inverted rift: The Castillian Branch of the Iberian Chain. Tectonophysics 470, 224-242.

Dercourt, J., Ricou, L. E., Vrielynck, B., 1993. Atlas Tethys palaeoenvironmental maps. Beicip- Fronlab, Rueil Malnaison.

Diedrich, C., 2008. Millions of reptile tracks-Early to Middle Triassic carbonate tidal flat migration bridges of Central Europe-reptile immigration into the Germanic Basin. Palaeogeography, Palaeoclimatology, Palaeoecology 259, 410-423. 
1027 Díez J B., Broutin J., Grauvogel-Stamm, L., Bourquin S., Bercovici, Ferrer J., 2010. 1028 Anisian Floras from the NE of Iberian Penninsula and Baléaric Island: a synthesis. 1029 Review of Paleobotany and Palynology 162, 522-542.

1030

Díez, J. B., Bourquin, S., Broutin, J., Ferrer, J., 2007. The Iberian Permian Triassic 1031

"Buntsandstein" of the Artagonian branch of the Iberian range (Spain) in the West1032 European sequence stratigraphical framework: a combined palynological and 1033 sedimentological approach. Bol. Soc. géol. Fr. 178 (3), 187-203.

1034

1035

Díez, J.B., 2000. Geología y Paleobotánica de la Facies Buntsandstein en la Rama 1036 Aragonesa de la Cordillera Ibérica. Implicaciones bioestratigráficas en el Perithetys 1037 Occidental. Ph.D Thesis. Universidad de Zaragoza (Spain) and Univ. Paris 6, (France). 1038 Unpublished.

1039

Díez, J.B., Arche, A., Broutin, J., Bourquin, J., De la Horra, R., Ferrer, J., García-Gil, 1040 S., López-Gómez, J. (2013). Palynostratigraphical data of the Buntsandstein and 1041 Muschelkalk facies from the Iberian Ranges (Spain). Ciencias da Terra VII, p. 170.

Díez, J.B., Grauvogel-Stamm, L., Broutin, J., Ferrer, J., Gisbert, J., Liñán, E., 1996. 1044 Première découverte d'eune paléoflore anisienne dans le faciès "Buntsanddstein" de la

1045 branche aragonaise de la Cordillère Iberique (Espagne). C. R. Acad. Sci. Paris 323 (2), $341-347$.

Dinarès-Terell, J., Díez, J.B., Rey, D., Arnal, I., 2005. "Buntsandstein" 1049 magnetostratigraphy and biostratigraphic reppraisal from eastern Iberia: Early-Middle 
1050 Triassic stage boundary definitions through correlation to tethyan sections.

1051 Palaeogeography, Palaeoclimatology, Palaeoecology 229, 158-177.

1052

1053 Dobruskina, I. A., 1994. Triassic floras of Eurasia. Österreichische Akademie der.

1054 Wissenschaften. Achriftenreihe der Erdwinssenchaftlinchen Kommissionem 10, 1-422.

1055

1056

Domeier M., Van der Voo R., H. Torsvik T., 2012. Paleomagnetism and Pangea: The

1057

road to reconciliation. Tectonophysics $514-517,14-43$.

1058

1059 Doubinger, J., López-Gómez, J., Arche, A., 1990. Pollen and spores from the Permian 1060 and Triassic sediments of the southeastern Iberian Ranges, Cueva de Hierro (Cuenca) to

1061 Chelva-Manzanera (Valencia-Teruel) region, Spain. Review of Palaeobotany and 1062 Palynology 66, 25-45.

1063 Durand, M., 2006. The problem of transition from the Permian to the Triassic series in 1064 southeastern France: comparison with other Peritethyan regions. In: Lucas, S.G., 1065 Cassinis, G., Schneider, J.W. (Eds.), Non-Marine Permian Biostratigraphy and 1066 Biochronology. Geol. Soc. Spec. Publ. 265, London, pp. 281-296.

1067

1068 Durand, M., 2008. Permian to Triassic continental successions in southern Provence 1069 (France): an overview. Boll. Soc. Geol. Ital. (Ital. J. Geosci.) 127, 697-716.

1070

1071 Erwin, D.H., 2006. Extinction. How Life on Earth Nearly Ended 250 Million Years 1072 Ago. Princenton University Press. Princenton, Oxford. 296 p. 
1073 Escudero-Escudero, M.J., Márquez-Aliaga, A., Goy, A., Martín-Chivelet, J., López-

1074 Gómez, J., Márquez, L., Arche, A., Plasencia, P., Pla, C., Marzo, M., Sánchez1075 Fernández, D., 2015. Middle Triassic carbonate platforms in eastern Iberia: Evolution of 1076 their fauna and palaeogeographic significance in the western Tethys. Palaeogeography, 1077 Palaeoclimatology, Palaeoecology 417, 236-260.

1078

1079 Escudero-Mozo, M.J., Martín-Chivelet, J., Goy, A., López-Gómez, J., 2014. Middle1080

1081 Upper Triassic carbonate platforms in Minorca (Balearic Islands): implications for western Tethys correlations. Sedimentary Geology 310, 41-58.

1082

1083

1084

Fielding, C., Allen, J.P., Alexander, J., Gibling, M.R., 2009. Facies model for fluvial systems in the seasonal tropics and subtropics. Geology 37 (7), 623-626.

1085

1086

1087

Flueau, F., 2003. Earth dynamics and climate changes. Comptes Rendus Geoscience $335,157-174$

1088

1089

Fluteau, F., Besse, J., Broutin, J., Ramstein, G., 2001. The Late Permian climate. What 1090 can be inferred from climate modelling concerning Pangea scenarios and Hercynian 1091 range altitude? Palaeogeography, Palaeoclimatology, Palaeoecology 167, 39-71.

1092

1093 Fortuny, J., Bolet, A., Sellés, A. G., Cartanyá, J., Galobart, À., 2011. New insights on 1094 the Permian and Triassic vertebrates from the Iberian Peninsula with emphasis on the 1095 Pyrenean and Catalonian basins. Journal of Iberian Geology 37 (1), 65-86.

1096 
Fuchs, G., Grauvogel-Stamm, L., Mader, D., 1991. Une remarquable flore à Pluromeia et Anomopteris mougeotti in situ du Buntsandstein moyen (Trias inférieur) de 1'Eifel (R.F. Allemagne). Morphologie, paléoécologie et paléogéographie, Palaoentographica $222,89-120$.

Gaete, R., Galobart, A., Palomar, J., Marzo, M., 1994. Hallazgo de Paratosuchs sp. (Amphibia, Temnospondyli) en facies Buntsandstein del Pla de la Calma (Cordilleras Costero Catalanas): Resultados preliminares. Geogaceta 16, 61-63.

Galán-Abellán, B., 2011. Variaciones sedimentarias, mineralógicas, geoquímicas y bióticas en el Triásico Inferior-Medio (en facies Buntsandstein) de las cordilleras Ibérica SE y Costero Catalana: Implicaciones en la recuperación de la crisis PermoTriásica. PhD Thesis. Universidad Complutense de Madrid. 295 p. Umpublished.

Galán-Abellán, B., López-Gómez, J., Barrenechea, J.F., Marzo, M., De la Horra, R., Arche, A., 2013a. The beginning of the Buntsandstein cycle (Early-Middle Triassic) in the Catalan Ranges, NE Spain: Sementary and palaeogeographic implications. Sedimentary Geology 296, 86-102.

Galán-Abellán, B., Alonso-Azcárate, J., Newton, R.J., Bottrell, S., Barrenechea, J.F., Benito, I., De la Horra, R., López-Gómez, J., Luque, J., 2013b. Soureces of Sr and S in aluminium-phosphate- sulphate minerals in Early-Middle Triassic sandstones (Iberian Ranges, Spain) and plalaeontological implications for the west Tethys. Jour. Sed. Res. $83,406-426$. 
1120 Galfetti, T., Hochuli, P., Brayard, A., Bucher, H., Weissert, H., Os Vigran, J., 2007.

1121 Smithian-Spathian boundary event: Evidence for global climatic change in the wake of 1122 the end-Permian biotic crisis. Geology 35 (4), 291-294

1123 Gand, G., De la Horra, R., Galán-Abellán, B., López-Gómez, J., Barrenechea, J., Arche, 1124 A., Benito, M.I., 2010. New ichnites from the Middle Triassic of the Iberian Ranges 1125 (Spain): Paleoenvironmental and palaeogeographical implications. Hist. Biol. 22 (1-3), $1126 \quad 40-56$.

1127 Gile, L.H., Peterson, F.F., Grossman, J.B., 1966. Morphological and genetic sequences 1128 of carbonate accumulation in desert soils. Soil Science 101, 347-360.

1129 Gisbert, J., 1981. Estudio geológico-petrológico del Estefaniense-Pérmico de la Sierra del Cadí (Pirineo de érida). PhD Thesis. Univ. Zaragoza. Unpublished.

1132 Gisbert, J., 1983. El Pérmico de los Pirineos españoles. In: Martínez García, E. (Ed.), 1133 Carbonífero y Pérmico de España. Ministerio de Industria y Energía, España, pp. 4051134 420.

1135

1136 Golonka, J., Ford, D., 2000. Pangean (Late Carboniferous-Middle Jurassic) 1137 paleoenvironment and lithofacies. Palaeogeography, Palaeoclimatology, Palaeoecology $1138161,1-34$.

1139

1140 Grauvogel-Stamm, L., Ash, S.R., 2005. Recovery of the Triassic land flora from the 1141 end-Permian life crisis. C.R. Palevol 4, 593-608. 
1143 Gretter, N., 2014. The Permian-Triassic stratigraphic evolution in selected Peri1144 Tethyan areas: facies analysis and U-Pb geochronology. $\mathrm{PhD}$ Thesis, Università di 1145 Pavia. Unpublished.

1146

1147 Hajek, E. A., Edmonds, D. A., 2014. Is river avulsion style controlled by floodplain 1148 morphodynamics? Geology 42 (3), 199-202.

1149

1150

Hajek, E. A., Heller, P. L., Sheets, B. A., 2010. Significance of channel-belt clustering 1151 in alluvial basins. Geology 38 (6), 535-538.

1152

1153

Hasiotis, S.T., 2002. Continental Trace Fossils: SEPM, Short Course Notes 51, 132 pp.

1154

Hervé, C., 1989. Clay Sedimentology. Springer Verlag. Berlin, Heidelberg. 623 p.

1155

Hillier, S., 1995. Erosion, sedimentation and sedimentary origin of clays. In: Velde, B.

1156

(Ed.), Origin and Mineralogy of Clays. Clays and the Environment, pp 162-219.

1157 Springer-Verlag. Berlin, Heidelberg.

1158 Hofmann, R., Goudemand, N., Wasmer, M., Bucher, H., Hautmann, M., 2011. New 1159 trace fossil evidence for an early recovery signal in the aftermath of the end-Permian 1160 mass extinction. Palaeogeography, Palaeoclimatology, Palaeoecology 310, 216-226.

1161 Hofmann, R., Hautmann, M., Bucher, H., 2013. A new palaeoecological look at the 1162 dinwoody Formation (Lower Triassic, Western USA): Intrinsic versus extrinsic controls 1163 on ecosystem recovery after the end-Permian mass extinction. Journal of Paleontology $116487,854-880$. 

clay mineralogy of the Linxia Basin: Evidence of paleoclimatic evolution subsequent to the initial-stage uplift of the Tibetan plateau. Clays and Clay Minerals 55, 491-503.

1168

1169 Joachimski, M. M., Lai, X., Shen, S., Jian, H., Lou, G., Chen, B., Chen, J., Sun, Y., 1170 2012. Climate warming in the latest Permian and Permian-Triassic mass extinction. 1171 Geology 40, 195-198.

1172

Jones, S. J., Frostick, L. E., Astin, T. R. 2001. Braided stream and flood plain architecture: the Rio Vero Formation, Spanish Pyrenees. Sedimentary Geology 139, 229-260.

1176

1177

Kearsey, T., Twitchett, R. J., Price, G. D., Grimes, S. T., 2009. Isotope excursions and 1178 palaeotemperature estimates from the Permian/Triassic boundary in the Southern Alps (Italy). Palaeogeography, Palaeoclimatology, Palaeoecology 279, 29-40.

1180

1181 Kider, D. L., Worsley, T. R., 2004. Causes and consequences of extreme Permo1182 Triassic warming to globally equable climate and relation to the Permo-Triassic extinction and recovery. Palaeogeography, Palaeoclimatology, Palaeoecology 203, 207237.

Kiehl, J. T., Shields, C. A., 2005. Climate simulation of the latest Permian: implications 1187 for mass extinction. Geology 33, 757-760. 
Kiehl, J. T, Shields, C. A., 2005. Climate simulation of the latest Permian: Implication 1190 for mass extinction. Geology 33, 757-760.

1191

1192

Klein, H., Voigt, S., Hminna, A., Saber, H., Schneider, J., Hmich, D., 2010. Early

Triassic Archosaur-Dominated Footprint Assemblage from the Argana Basin (Western

1194 High Atlas, Morocco). Ichnos 17, 215-227.

1195

1196

Kozur, H. W., Weems, R. E., 2011. Detailed correlation and age of continental late

Changhsingian and earliest Triassic beds: Implications for the role of the Siberia trap in the Permian-Triassic biotic crisis. Palaeogeography, Palaeoclimatology, Palaeoecology $308,22-40$.

1200

1201

1202

1203

1204

1205

1206

1207

(Germany). Palaeodivers. Palaeoenvirons. 94, 237-270.

1208

Kutzbach, J.E., Gallimore, R.G., 1989. Pangean climates: megamonsoon of the megacontinent. Journal of Geophysical Research 94, 3341-3357.

1211

1212

Loope, D.B., 1988. Rhizoliths and ancient aeolianites. Sedimentary Geology 56, 301314. 
López-Gómez, J., Arche, A., 1993. Architecture of the Cañizar fluvial sheet sandstones.

In: Marzo, M., Puigdefábregas, C. (Eds.), Alluvial Sedimentation. Spec. Publ. Int. Ass.

Sedimentol. 17, 363-381. Blackwell Scientific Publications, Oxford.

1218

López-Gómez, J., Arche, A., De la Horra, R., Galán-Abellán, B., Barrenechea, J.F., 1220 2011. Permian-Triassic continental rocks of the SE Iberian Ranges: architecture, 1221 tectonics and geochemical characteristics in the context of a rift basin. In: Arenas, C., Meeting, Zaragoza. Sociedad Geológica de España. Geo-Guías 8, 11-43.

López-Gómez, J., Galán-Abellán, B., De la Horra, R., Barrenechea, J. F., Arche, A., 1226 Bourquin, S., Marzo, M., Durand, M., 2012. Sedimentary evolution of the continental Early-Middle Triassic Cañizar Formation (Central Spain): implications for life recovery after the Permian-Triassic crisis. Sedimentary Geology 249-250, 26-44.

Machette, M. N., 1985. Calcic soils of the southwestern United States. In: Weide, D. L. 1231 (Ed.), Soils and Quaternary Geology of the Southwestern United States. Spec. Pap. 1232 Geol. Soc. Amer. 203, 10-21.

Mader, D., 1990. Palaeocology of the flora in Buntsandstein and Keuper in the Triassic of Middle Europe. G. Fischer Verlag, Stuttgart, New York. 1582 p. 
Martín-Martín, J. D., Gómez-Gras, D., Sanfeliu, T., Thiry, M., Ruiz-Cruz, M. D.,

1238

1239

1240

1241

1242

1243

1244

1245

1246

1247

1248

1249

1250

1251

1252

1253

1254

1255

1256

1257

1258

1259

Franco, F., 2007. Extensive dickitization of the Permo-Triassic fluvisl sandstones from the eastern Iberian Range, Spain. Clays and Clay Minerals 55 (5), 481-490.

Marzo, M., 1980. El Buntsandstein de los Catalánides: Estratigrafía y procesos de sedimentación. Ph.D Thesis. Barcelona University. Unpublished.

Marzo, M., 1986. Secuencias fluvio-eólicas en el Buntsandstein del Macizo de Garraf (provincia de Barcelona). Cuad. Geol. Iber. 10, 207-233.

Marzo, M., Anadón, P., 1977. Evolución y características sedimentológicas de las facies fluviales basales del Buntsandstein de Olesa de Montserrat (provincia de Barcelona). Cuadernos de Geología Ibérica 4, 211-222.

Marzo, M., Esteban, M., Pomar, L., 1974. Presencia de caliche fósil en el Buntsandstein del valle del Congost (Provincia de Barcelona). Acta Geológica Hispánica IX (2), 3336.

McKie, T., Williams, B., 2009. Triassic palaeogeography and fluvial dispersal across the northwest European Basins. Geological Journal 44, 711-741.

Miall, A.D., 1992. Alluvial Deposits. In: Walker, R.G., James, N.P. (Eds.), Facies Models: response to sea level change. Geological Association of Canada. St. John's, Newfounland, pp. 119-142

Miall, A.D., 1996. The Geology of Fluvial Deposits. Sedimentary Facies, Basin Análisis and Petroleum Geology. Springer-Verlag. Berlin. 582 p. 
1260

1261

1262

1263

1264

1265

1266

1267

1268

1269

1270

1271

1272

1273

1274

1275

1276

1277

1278

1279

1280

Middleton, G. V., Trujillo, A., 1984. Sedimentology and depositional setting of the Upper Proterozoic Scanlan Conglomerate, Central Arizona. In: Koster, E. H., Steel, R. (Eds.), Sedimentology of gravels and conglomerates. Mem. Can. Soc. Petrol. Geol. 10, 189-201.

Montañez, I., Tabor, N., Niemeier, D., DiMichele, W., Frank, T. D., Fielding, C. R., Isbell, J., Birgenheier, L.P., Rygel, M.C., 2007. $\mathrm{CO}_{2}$-Forced climate and vegetation instability during Late Paleozoic deglaciation. Science 315, 87-89.

Mountney, N. P., 2006. Eolian Facies Models. In: Posamentier, H. W., Walker, R. G. (Eds.), Facies Models Revisited. SEPM Special Publication 84, pp. 19-83.

Mountney, N. P., 2012. A stratigraphic model to account for complexity in aeolian dune and interdune successions. Sedimentology 59, 964-989.

Muttoni, G., Gaetani, M., Kent, D.V., Sciunnach, D., Angiolini, L., Berra, F., Garzanti, E., Mattei, M., Zanchi, A., 2009. Opening of Neo-Tethys Ocean and Pangea B to Pangea A transformation during the Permian. GeoArabia 14 (4), 17-48.

Nemec, W., Postma, G., 1993. Quaternary alluvial fans in Southeastern Creta: Sedimentation, Processes and geomorphic evolution. In: Marzo, M., Puigdefábregas, C. (Eds.), Alluvial Sedimentation. Int. Assoc. Sedimentol. Spec. Publ. 17, 235-276. 
Nikishin, A. M., Ziegler. P. A., Abbott, D., Brunet, M.-F., Cloetingh, S., 2002. Permo-

Triassic intraplate magmatism and rifting in Eurasia: implications for mantle plumes and mantle dynamics. Tectonophysics 351, 3-39.

1285

Ogg, J.G., Huang, C., Hinnov, L., 2014. Triassic timescale status: A brief overview. 1287 Albertiana 41, 3-30.

1288

1289

Oyarzun, R., Doblas, M., López-Ruiz, J., Cebriá, J.M., Youbi, N., 1999. Tectonicallyinduced icehouse-hothouse climate oscillations during the transition from the Variscan to the Alpine cycle (Carboniferous to Triassic). Bulletin de la Societé Géologique de France 170, 3-11.

1293

1294

Payne, J. L., Lehrmann, D. J., Wei, J., Orchard, M. J. Scharg, D. P., Knoll, A. H., 2004.

1295

Large perturbations of the carbon cycle during recovery from the end-Permian 1296 extinction. Science 305, 506-509.

1297

Payne, J. L., Kump, L. R., 2007. Evidence for recurrent Early Triassic massive 1298 volcanism from quantitative interpretation of carbon isotope fluctuations. Earth and Planetary Science Letters 256, 264-277.

1300

1301

Pecorini G., 1962. Nuove osservazioni sul Permico della Nurra (Sardegna nord1302 occidentale). Atti Acc. Naz. Lincei, Rend. Cl. fis. mat. e nat. 8 (32) 377-380.

1303

1304 Pittau, P., Del Rio M., 2002. Palynofloral biostratigraphy of the Permian and Triassic 1305 sequences of Sardinia. Rend. Soc. Paleont. It. 1, 93-109. 
1307 Posenato, R., 2008. Patterns of bivalve biodiversity from Early to Middle Triassic in the 1308 Southern Alps (Italy): Regional vs. global events. Palaeogeography, Palaeoclimatology, 1309 Palaeoecology 261, 145-159.

1310

Preto, N., Kustatscher, E., Wignall, P.B., 2010. Triassic climates - State of the art and perspectives. Palaeogeography, Palaeoclimatology, Palaeoecology 290, 1-10.

Ramos, A., 1995. Transition from alluvial to coastal deposits (Permian-Triassic) on the

Island of Mallorca, western Mediterranean. Geological Magazine 132, 435-447.

1316

Ramos, A., Doubinger, J., 1989. Premières datations palynologiques dans le faciès 1318

Buntsandstein de 1'Ile de Majorque (Baleares, Espagne). C. R. Acad. Sci., Paris, Ser. 2 (309), 1089-1094.

1320

Retallack, G., Sheldon, N. D., Carr, P. F., Fanning, M., Thompson, C. A., Williams, M.

L., Jones, B. G., Hutton, A., 2011. Multiple Early Triassic greenhouse crises impeded 1323 recovery from Late Permian mass extinction. Palaeogeography, Palaeoclimatology, Palaeoecology 308, 233-251.

Retallack, G. J., 1977. A Colour Guide to Paleosols. John Wiley and Sons, Chichester, 1327 England, $175 \mathrm{pp}$.

1328 Retallack, G.J., 1988. Field recognition of paleosols. In: Reinhardt, J., Sigleo, W. R. 1329 (Eds), Paleosols and Applications. Spec. Pap. Geol. Soc. Amer, 216, 1-21. 
Retallack, G. J., 2005. Pedogenic carbonate proxies for amount and seasonality of precipitation in paleosols. Geol. Soc. Am. 33, 333-336.

Righi, D., Meunier, A., 1995. Origin of Clays by Rock Weathering and Soil Formation. 1333 in: Velde, B. (Ed.), Origin and Mineralogy of Clays. Springer-Verlag BerlinHeidelberg, 43-161.

1335

Rodríguez-López, J., Meléndez, M. N., De Boer, P., Soria, A. R., 2011. Control on marine erg-margin cycle variability: aeolian-marine interaction in the mid-Cretaceous Iberian Desert System, Spain. Sedimentology 59 (2), 466-501.

1339

Röhling, H. G., 1991. A lithostratigraphic subdivisión of the Lower Triassic in the Northwest German Lowlands and the German sector of the North Sea, based on gamma-ray and sonic logs. Geologisches Jahrbuch A 119, 3-24.

Romano, C., Goudemand, N., Vennemann, T.W., Ware, D., Schneebeli-Hermann, E., Hochuli, P. A., Binkmann, W., Bucher, H., 2013. Climatic and biotic upheavals following the end-permian mass extinction. Nature Geoscience 6, 57-60.

Ronchi, A., Gretter, N., López-Gómez, J., Arche, A., De la Horra, R., Barrenechea, J., Lago, M., 2014. Facies analysis and evolution of the Permian and Triassic volcanosedimentary succession in the Eastern Pyrenees (Spain) and its regional correlation in the western Peri-Tethys. Carboniferous-Permian Meeting Freiberg, Abstract book, pp. 20-22. 
1354 Roscher, M., Stordal, F., Svensen, H., 2011. The effect of global warming and

1355

1356

1357

1358

1359

1360

1361

1362

1363

1364

1365

1366

1367

1368

1369

1370

1371

1372

1373

1374

1375

1376

globalcooling on the distribution of the latest Permian climate zones. Palaeogeography,

Palaeoclimatology, Palaeoecology 309, 186-200.

Schmidt, M., 1937. Probleme der westmediterranen Kontinentaltrias und Versuche ihrer Lösung. Association pour l'étude géologique de la Méditerranée occidental 4, (11), 357.

Self, S., Blake, S., Sharma, K., Widdowson, M., Sephton, S., 2008. Sulfur and chlorine in Late Cretaceous Deccan magmas and eruptive gas release. Science 319, 1654-1657.

Sellwood, B.W., Valdes, P.J., 2007. Mesozoic climates. In: Williams, M., Haywood, A.M., Gregory, F.J., Schmidt, D.N. (Eds.), Deep-Time Perspectives on Climate Change: Marrying the signal from Computer Models and Biological Proxies. The Micropalaeontological Society, Special Publication. The Geological Society, London, $201-224$.

Smith, R. M. H., 1995. Changing fluvial environments across the Permian-Triassic boundary in the Karoo Basin, South Africa and possible causes of tetrapods extinctions. Palaeogeography, Palaeoclimatology, Palaeoecology 117, 81-104.

Soil Survey Staff (1999): Keys to Soil Taxonomy. Pocahontas Press, Blackburg. 600 pp. 
Soria, A. R., Liesa, C., Rodríguez-López, J. P., Meléndez, N., De Boer, P., Meléndez,

1378

1379

1380

1381

1382

1383

1384

1385

1386

1387

1388

1389

1390

1391

1392

1393

1394

1395

1396

1397

1398

1399

1400

A., 2011. An Early Triassic evolving erg system (Iberian Chain, NE Spain):

Paleoclimate implications. Terra Nova 23, 76-84.

Stampfli, G. M., Borel, G. D., 2002. A plate tectonic model for the Paleozoic and Mesozoic constrained by dynamic plate boundaries and restored synthetic oceanic isochrones. Earth and Planetary Science Letters 196, 17-33.

Stefani, M., Furin, S., Gianolla, P., 2010. The changing climate framework and depositional dynamics of Triassic carbonate platforms from the Dolomites. Palaeogeography, Palaeoclimatology, Palaeoecology 290, 43-57.

Sun, Y., Joachimski, M., Wignall, P. B., Yan, C., Chen, Y., Jiang, H., Wang, L., Lai, X., 2012. Lathally hot temperatures during the Early Triassic greenhouse. Science 338, $336-370$.

Takahashi S., Yamasaki S., Ogawa K., Kaiho K., Tsuchiya N. (in press). Redox conditions in the end-Early Triassic Panthalassa. Palaeogeography, Palaeoclimatology, Palaeoecology. DOI: doi: 10.1016/j.palaeo.2015.04.018

Tourani, A., Benaouiss, N., Gand, G., Bourquin, S., Jalil, N-E., Broutin, J., Battail, B., Germain, D., Khaldoune, F., Sebban, S., Steyer, J-S., Vacant, R., 2010. Evidence of an Early Triassic age (Olenekian) in Argana Basin (High Atlas, Morocco) based on new chirotherioid traces. Comptes Rendus Palevol 9, 201-208. 
1402 Twitchett, R. J., 2007. Climate change across the Permian/Triassic boundary. In:

1403 Williams, M., Haywood, A., Gregory, F., Schmidt, D. N. (Eds.), Deep-Time 1404 Perspectives on Climate Change: Marrying the Signal from Computer Models and 1405 Biological Proxies. The Micropaleontological Society, Special Publications. The 1406 Geological Society, London, pp. 191-200.

1407

1408

Twitchett, R.J., 2006. The palaeoclimatology, palaeoecology and palaeoenvironmental 1409 analysis of mass extinction events. Palaeogeography, Palaeoclimatology, Palaeoecology $232,290-213$.

Tyrrell, S., Haughton, P. B. W., Souders, A.K., Daly, J. S., Shanonn, P. M., 2012. 1413 Large-scale, linked drainage systems in the NW European Triassic. Insights from the $\mathrm{Pb}$ 1414 isotopic composition of detrital K-feldspar. Journal of the Geological Society, London $169,279-295$.

Velde, B., Meunier, A. 2008. The Origin of Clay Minerals in Soils and Weathered Rocks. Springer-Verlag, Berlin-Heidelberg. 406 pp.

Van Wees, J-D., Arche, A., Beijdorff, C. G., López-Gómez, J., Cloetingh, S.A.P.L., 1998. Temporal and spatial variations in tectonic subsidence in the Iberian Basin 1421 (eastern Spain): inferences from automated forward modelling of high-resolution stratigraphy (Permian-Mesozoic). Tectonophysics 300, 285-310.

1424 Vargas, H., Gaspar-Escribano, J., López-Gómez, J., van Wees, J-D., Cloetingh, S., De 1425 la Horra, R., Arche, A., 2009. A comparison of the Iberian and Ebro Basins during the 
1426 Permian and Triassic, eastern Spain: A quantitative subsidence modelling approach.

1427 Tectonophysics 474, 160-183.

1428

1429 Wand, C., Hong, H., Li, Z., Yin, K., Xie, J., Liang, G., Song, B., Zhang, K., 2013. The 1430 Eocene-Oligocene climate transition in the Tarim Basin, Northwest China: Evidence 1431 from clay mineralogy. Applied Clay Science 74, 10-19.

1432 Weil, A. B., Van der Voo, R., Van der Pluijm, B., 2001. Oroclinal bending and 1433 evidence against the Pangea megashear: the Cantabria-Asturias arc (northern Spain). 1434 Geology 29 (11), 991-994.

Wignall, P. B., 2007. The end-Permian mass extinction-how bad did it get? Geobiology 5, 303-309.

1438

1439

Wignall, P.B., 2001. Large igneous provinces and mass extinctions. Earth-Science 1440 Review 53, 1-33.

Willis, B. J., 1989. Palaeochannel reconstruction from point bar deposits: a threedimensional perspective. Sedimentology 36, 757-766.

1444 northern Pakistan. Jour. Sediment. Res. 64, 60-67. 
1448 Yakimenko, E., Targul'yan, V., Chumakov, N., Arefev, M., Inozemtsev, S., 2000.

1449 Paleosols in Upper Permian sedimentary rocks, Sukhona River (Severnaya Dvina 1450 basin). Lithology and Mineral Resources 35, 331-344.

1451

1452 Yin, H., Song, H., 2013. Mass extinction and Pangea integration during the Paleozoic1453 Mesozoic transition. Science China: Earth Sciences 56 (11), 1791-1803.

1454

1455

Ziegler, P. A., 1988. Post-Hercynian plate reorganization in the Tethys and Artic-North 1456 Atlantic domains. In: Manspeizer, W. (Ed.), Triassic-Jurassic Rifting. Developments in 1457 Geotectonics 22. Elsevier, Amsterdam, pp 711-755.

1458

Ziegler, P.A., Stampfli, G.M., 2001. Late Paleozoic-Early Mesozoic plate boundary 1459 reorganization: Collapse of the Variscan Orogen and opening of the Neotethys. Nature 1460 Bresciana. Ann. Mus. Civ. Sc. Nat. Bresc. 25, 17-34.

1461

1462

1463

1464

1465

1466

1467

1468

1469

1470

1471 
Fig. 1. Early Triassic global map showing the configuration of the continents (modified from Golonka and Ford, 2000; Yin and Song, 2013). The amplified area corresponds to the Iberian peninsula and the present-day basin and ranges: 1- Pyrenean Ranges, 2-

1477 Catalan Ranges, 3- Ebro Basin, 4- Duero Basin, 5Iberian Ranges, 6- Tagus Basin, 7Guadalquivir Basin, 8- Betic Ranges, 9- Iberian Massif, 10- Balearic Islands.

Fig. 2. Lithostratigraphic scheme of the Middle Permian - Middle Triassic units of the studied areas and their comparison with coeval units of NE Sardinia and Minorca. Numbers 1 to 12 represent sections cited in the text: 1- Río Mayor, 2- Gátova, 3Cedrillas-Corbalán, 4- Torre de Las Arcas - Peñarroyas, 5- Benicassim, 6- Novés, 7Castellar d’Hug, 8- San Gregori, 9: Cervelló, 10- El Brull-Figaró, 11- Cala Pilar, 12Cala Viola. Their geographical location are indicated down to the right in the figure.

Fig. 3. a) The Cañizar Fm. in S. Iberian Ranges. Lines represent major boundaries 1488 surfaces (MBS) and separate subunits (A to F). The lower contact is an unconformity that separates the Triassic to the Permian (Alcotas Fm.) (Photograph modified from López-Gómez et al., 2012). b) The Eslida Fm. in the E Iberian Ranges.

Fig. 4. Main characteristics and references of the lithological units of the studied areas.

Fig. 5. Studied Lower-Middle Triassic sections and their main sedimentary and 
architectural elements is shown in figure 7. $\mathrm{C} 1$ to $\mathrm{C} 6$ and Ems-3 to Ems-6 represents subunits of the Cañizar Fm. and Eslida Fm. respectively.

1499

1500

Fig. 6. Description, interpretation and codes of the main and secondary fluvial and aeolian facies.

1502

1503

1504

Fig. 7. Fluvial and aeolian architectural elements showing their codes, facies associations, hierarchy and vertical stacking patterns, and selected references.

1505

1506

Fig. 8. Pictures of the different described architectural elements: a) element GB in the

1507 Garraf Upper Conglomerates Unit (GUC), Catalan Ranges; b) element GM in the 1508 Prades Upper Conglomerates Unit (PUC), Catalan Ranges; c) SB and CH elements in 1509 the Cañizar Fm. (CS), Iberian Ranges; d) E1 element in Prades Lower Sandstone Unit (PLS), Catalan Ranges; e) E2 and E3 elements in Prades Lower Sandstone (PLS), Catalan Ranges; f) FF element in Figaró Sandstones and Mudstones (FSM), Catalan Ranges; f) GB element in the lowermost part of the "Buntsandstein" deposits of the Noves section, Pyrenean Ranges; h) E1 element in the lower Buntsandstein of the 1514 Noves section, Pyrenean Ranges. See figure 5 for the location of these units and sections.

1517 Fig. 9. Sketches of 3D evolution of three selected stages of the Buntsandstein of the 1518 Iberian Ranges showing alluvial evolution and macroflora distribution (modified from 1519 Borruel-Abadía et al., 2014).

1520 
1521 Fig. 10. Specimens of macroflora from the Eslida Fm. in the Iberian Ranges. a:

1522 Pleuromeia sternbergii (Münster) Corda ex Giebe, 1953; b: Sphenophytes, most likely

Equisetitesmougeotii Brongniart 1828; c: Pelourdea vogesiaca (Schimper et Mogeot)

1524 Seaward 1917; d: Albertia latifolia Schimper et Mougeot 1944. Scale bar: $1 \mathrm{~cm}$.

1525

1526

Fig. 11. A) Dispersed carbonate nodules are circled in the subsurface horizon of the

1527

Gat-A pedotype. Black arrows are pointing to small green root traces. B) Calcareous,

1528 rooted, and endurated yellow B horizons are irregularly truncated in the Pedotype Gat-

1529

B. C) Adventitious prop roots (marked in white) emanating from a main root in the Gat-

1530

C pedotype. White arrow is pointing to the top of another unmarcked prop root pattern.

1531

1532

D) Deep penetrating tap root with root apex (r) related to Gat-C paleosols. E) Drabhaloes of light green silt around root traces in the pedotype Gat-D.

1533

1534

1535

1536

1537

Fig. 12. Synthesis of the main climate stages and their vertical alternating disposition during the Smithian to Pelsonian time - interval in the continental units (Buntsandstein) of the S. Iberian Ranges, E. Pyrenees and Catalan Ranges, and their relationship with fossil content. Sections (numbers 1 to 10) are located and named in figures 2 and 5.

1538

1539

Fig. 13. Early Triassic palaeogeographical reconstruction of Iberia and neighbour areas. Basins in Iberia were separated by elevated areas linked to the development of rift systems. Palaeolatitudes and sedimentary environments are partially based on Ziegler

1542 (1988), Dercourt et al. (1993), Mckie and Williams (2009), Bourquin et al. (2011) and 1543 Tyrrell et al. (2012). 


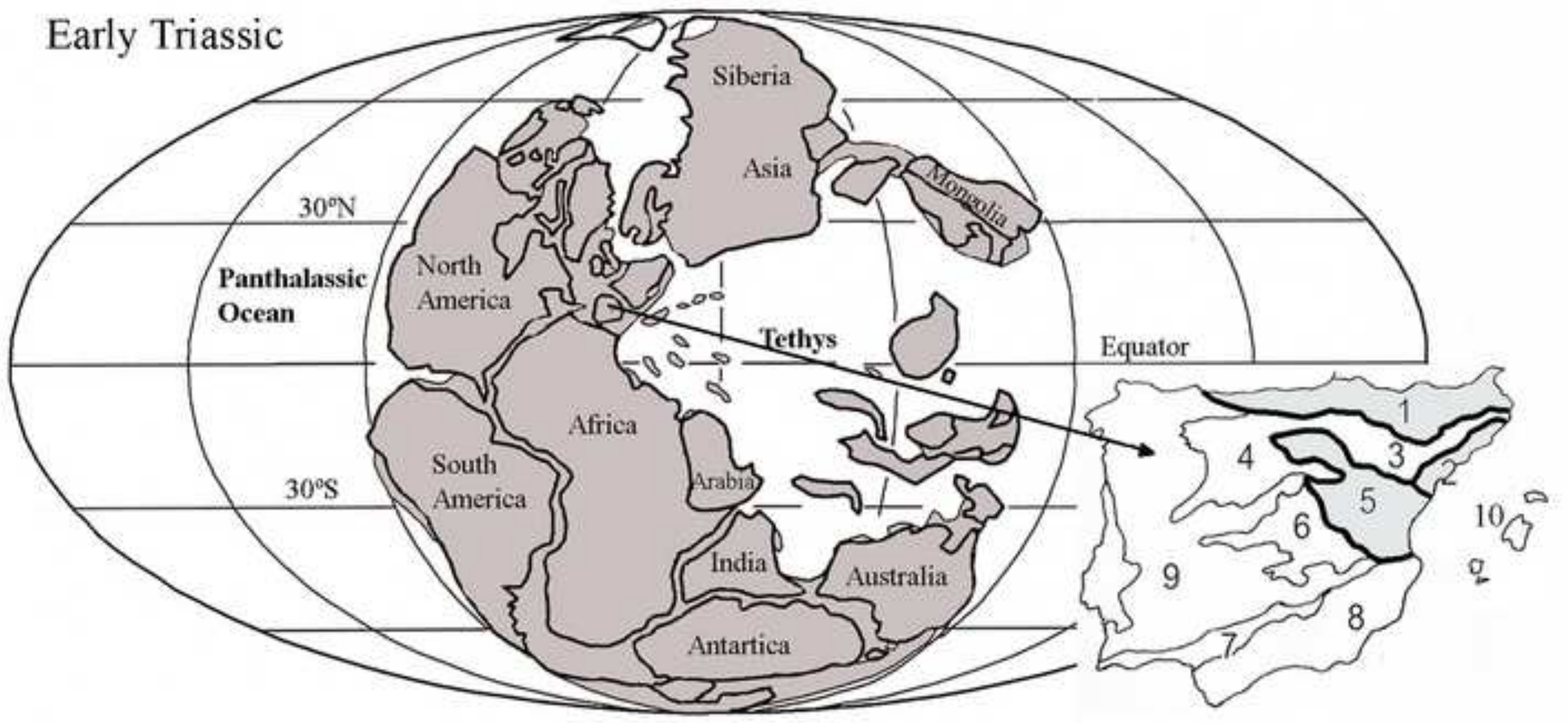




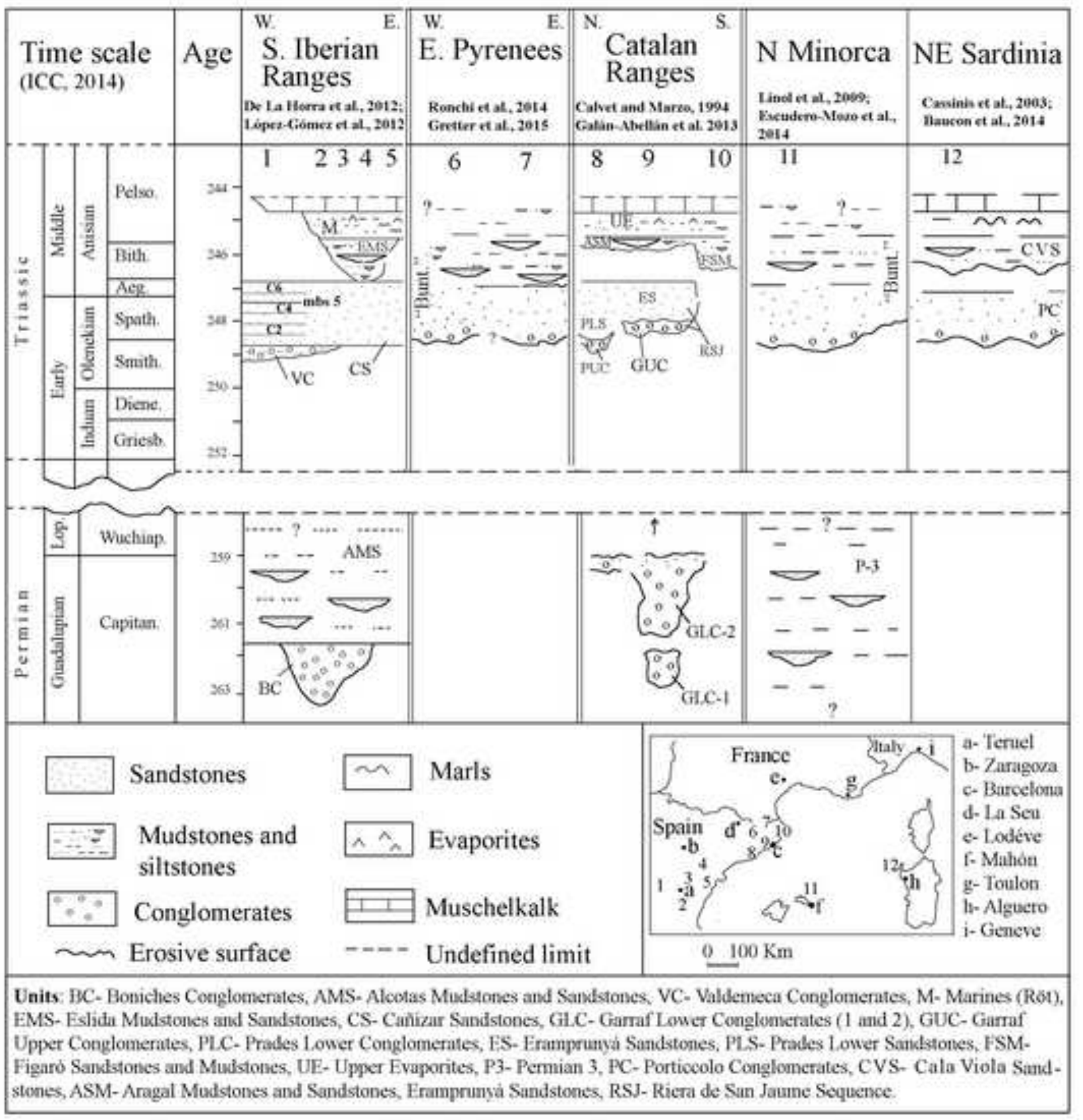


Click here to download high resolution image
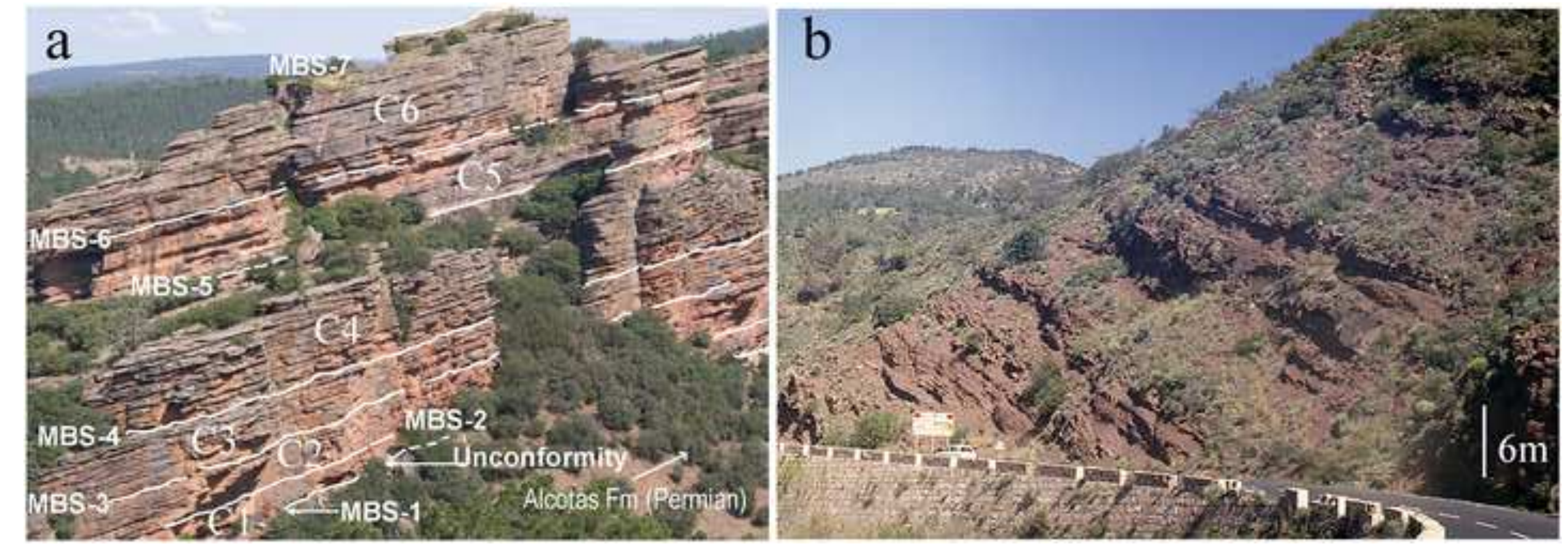


\begin{tabular}{|c|c|c|c|c|c|c|}
\hline \multicolumn{2}{|c|}{ Area } & Lithology & \multicolumn{2}{|c|}{$\begin{array}{l}\text { Palaeontological Age } \\
\text { content and soils }\end{array}$} & Interpretation & References \\
\hline \multirow{3}{*}{ 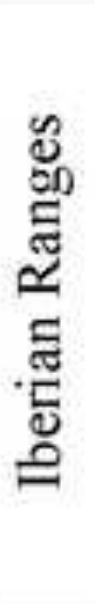 } & Eslida Fm. & $\begin{array}{l}\text { Mudstones } \\
\text { Sandstones }\end{array}$ & $\begin{array}{l}\text { Plants, footprints } \\
\text { Pollen assemblages } \\
\text { Soils }\end{array}$ & $\begin{array}{l}\text { Aegian- } \\
\text { Bithinian }\end{array}$ & $\begin{array}{l}\text { Alluvial and } \\
\text { punctual aeolian }\end{array}$ & $\begin{array}{l}\text { López-Gómez and Arche } \\
\text { (1993), Arche and López } \\
\text { Gómez (1999), Borruel } \\
\text { et al. (2014) }\end{array}$ \\
\hline & $\begin{array}{l}\text { Cañizar } \\
\text { Fm. }\end{array}$ & Sandsones & $\begin{array}{l}\text { Pollen assemblage } \\
\text { Plants, footprints }\end{array}$ & $\begin{array}{l}\text { Smithian } \\
\text { Aegian }\end{array}$ & $\begin{array}{l}\text { Fluvial (braided) } \\
\text { and aeolian }\end{array}$ & $\begin{array}{l}\text { Arche and López-Gómez } \\
(2005) \text {, López-Gómez et } \\
\text { al. (2013) }\end{array}$ \\
\hline & $\begin{array}{l}\text { Valdemeca } \\
\text { Unit }\end{array}$ & Conglomerates & $\ldots$ & Smithian & $\begin{array}{l}\text { Fluvial (braided, } \\
\text { unconfined), aeolian }\end{array}$ & $\begin{array}{l}\text { De la Horra et al. (2005) } \\
\text { De la Horra (2008) }\end{array}$ \\
\hline \multirow{4}{*}{ 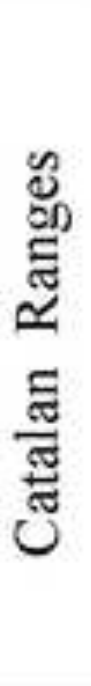 } & $\begin{array}{l}\text { Figaró } \\
\text { Unit }\end{array}$ & $\begin{array}{l}\text { Mudstones } \\
\text { Sandstones }\end{array}$ & \multirow[t]{2}{*}{$\begin{array}{l}\text { Footprints, bones, } \\
\text { Pollen assemblages } \\
\text { Soils }\end{array}$} & $\begin{array}{l}\text { Aegian- } \\
\text { Bithinian }\end{array}$ & $\begin{array}{l}\text { Fluvial (braided } \\
\text { and meander) }\end{array}$ & $\begin{array}{l}\text { Calvet and Marzo (1994) } \\
\text { Dinarès-Turell et al.(2005) }\end{array}$ \\
\hline & $\begin{array}{l}\text { Prades } \\
\text { Lower Sands. } \\
\text { Unit }\end{array}$ & Sandstones & & $\begin{array}{l}\text { Smithian } \\
\text { - Aegian }\end{array}$ & $\begin{array}{l}\text { Aeolian (dominating) } \\
\text { fluvial (braided) }\end{array}$ & $\begin{array}{l}\text { Marzo (1980), Calvet } \\
\text { and Marzo (1994), Galán- } \\
\text { Abellán et al. (2013) }\end{array}$ \\
\hline & Eramprunyả & Sandstones & \multirow[t]{2}{*}{ Plants } & $\begin{array}{l}\text { Smithian } \\
\text { - Aegian }\end{array}$ & $\begin{array}{l}\text { Fluvial (dominating) } \\
\text { aeolian }\end{array}$ & $\begin{array}{l}\text { Marzo (1980), Calvet } \\
\text { and Marzo (1994), Galản- } \\
\text { Abellán et al. (2013a) }\end{array}$ \\
\hline & $\begin{array}{l}\text { Garraf Upper } \\
\text { Conglo. Unit }\end{array}$ & Conglomerates & & Smithian & $\begin{array}{l}\text { Fluvial (dominating) } \\
\text { aeolian }\end{array}$ & $\begin{array}{l}\text { Calvet and Marzo (1994) } \\
\text { Dinarès-Turell et al. (2005) }\end{array}$ \\
\hline ¿્ఖ & $\begin{array}{l}\text { "Upper Bunt" } \\
\text { Unit }\end{array}$ & $\begin{array}{l}\text { Mudstones } \\
\text { Sandstones } \\
\text { Conglomerates }\end{array}$ & $\begin{array}{l}\text { Footprints, pollen } \\
\text { assemblages }\end{array}$ & $\begin{array}{l}\text { Spathian- } \\
\text { Anisian }\end{array}$ & $\begin{array}{l}\text { Fluvial (dominating) } \\
\text { aeolian }\end{array}$ & $\begin{array}{l}\text { Gisbert (1980), Ronchi et } \\
\text { al. (2014), Gretter (2014) }\end{array}$ \\
\hline
\end{tabular}




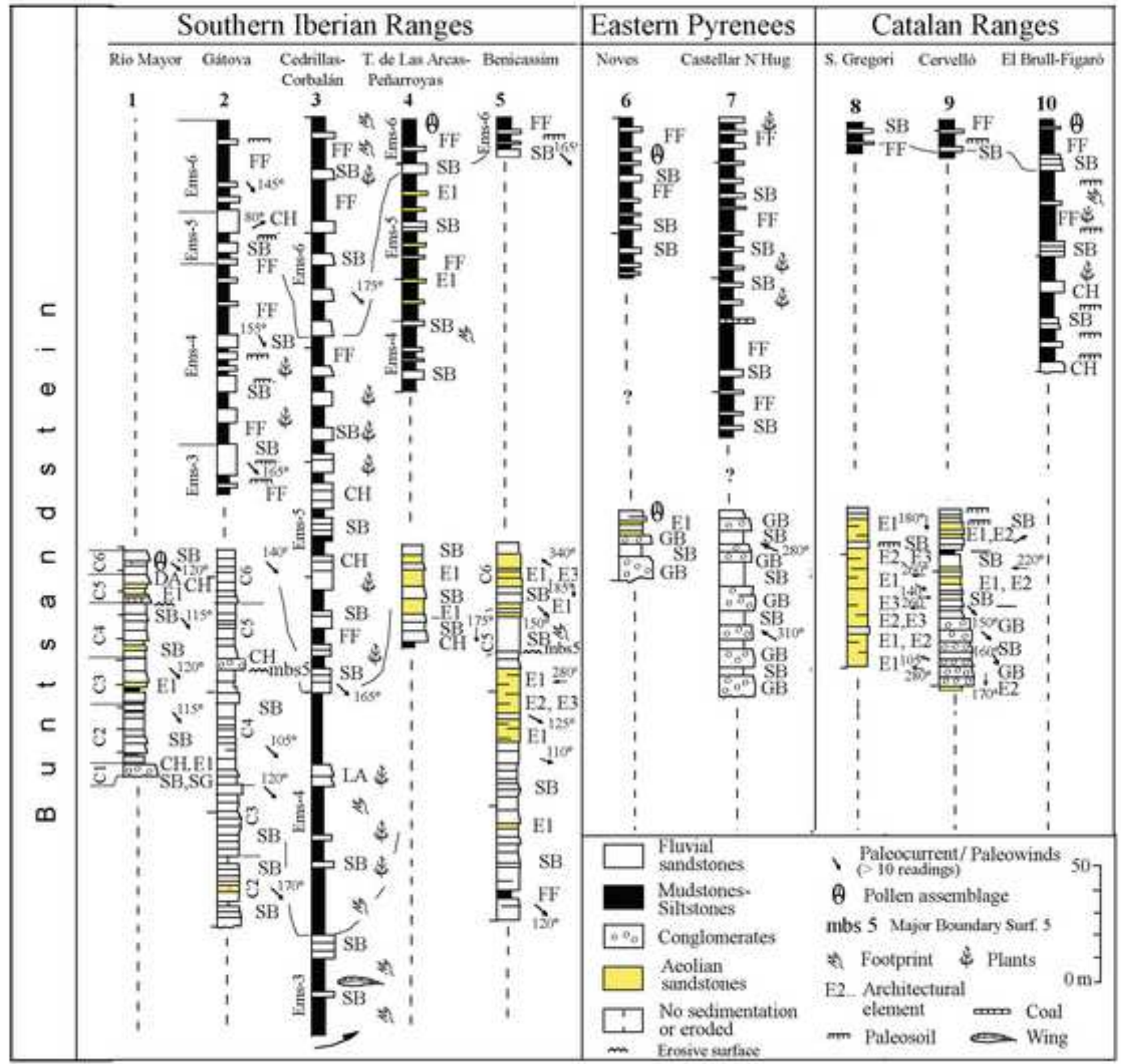




\begin{tabular}{|c|c|c|c|c|c|}
\hline & Architectural Elements & Code & $\begin{array}{l}\text { Facies: Main (above) } \\
\text { Associated (below) }\end{array}$ & $\begin{array}{l}\text { Hierarchy and vertical } \\
\text { stacking patterns }\end{array}$ & References \\
\hline $\begin{array}{l}\frac{d}{4} \\
\frac{1}{2} \\
\overrightarrow{4}\end{array}$ & $\begin{array}{l}\text { Megaripples of sandstones with erosive } \\
\text { or planar base and basal lag. } \\
\text { Channel-fill complex of sandstones with } \\
\text { defined margings and internal erosive } \\
\text { surfaces. } \\
\text { Lateral-accretion deposits showing } \\
\text { 3rd-order internal surtaces and up to } \\
1.5 \text { m thick. } \\
\text { Gravel bars normally amalgamated } \\
\text { into macroforms. } \\
\text { Unconfined or semiconfined clast } \\
\text { bodies. Beds show crude-masive } \\
\text { stratification. Sets up to } 1 \mathrm{~m} \text { thick. } \\
\text { Floodplain fines with isolated sandstone } \\
\text { bodies and paleosols } \\
\text { Crevasse splay deposits prograding } \\
\text { into floodplain. }\end{array}$ & $\begin{array}{l}G M \\
F F\end{array}$ & $\begin{array}{l}\text { St, Sp } \\
\text { Sh, Sr, ae4 } \\
\text { Sp, St. } \\
\text { Sh, Sr } \\
\text { St, Sp, Sr } \\
\text { Sh } \\
\text { Gp, Gmp, Gmt, Gt. } \\
\text { Sp } \\
\text { Gms } \\
\text { Gmp, St } \\
\text { Fr } \\
\text { Fb, Fl, Sbp } \\
\text { Fr, Sr } \\
\text { Sh }\end{array}$ & $\mid 10.8 \mathrm{~m}$ & $\begin{array}{l}\text { Blodgett and Stanley (1980) } \\
\text { Fielding et al. (2009) } \\
\text { Best et al. (2003) } \\
\text { Marzo and Anadon (1987) } \\
\text { Hajek et al. (2010) } \\
\text { Willis (1989) } \\
\text { Bristow (1993) } \\
\text { Middleton and Trujillo (1984) } \\
\text { Nemec and Postma (1993) } \\
\text { Nemee and Postma (1993) } \\
\text { Jones et al. (2001) } \\
\text { Allen and Ficlding (2007) } \\
\text { Hajek and Edmonds (2014) } \\
\text { Willis and Behrensmeyer (1994) } \\
\text { Hampton and Horton (2007) }\end{array}$ \\
\hline 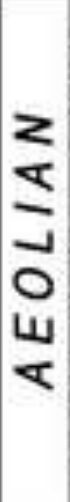 & $\begin{array}{l}\text { Dune. They may interact with sediments } \\
\text { of fluvial origin, and constitute sets up } \\
\text { to } 10 \mathrm{~m} \text { thick. } \\
\text { Sandsheet. They may show translatent- } \\
\text { strata, and constitute sets up to } 1 \mathrm{~m} \text { thick } \\
\text { and few tens of meters of lateral extension } \\
\begin{array}{l}\text { Interdune. They show irregular lenses of } \\
\text { fine-grained massive sandstones of pale- } \\
\text { brown color and occasional mottling. }\end{array}\end{array}$ & E2 & $\begin{array}{l}a e 1, a e 2, a e 3, a e 4 . \\
a d, v s, d s, r s, d f, w l, p l \\
a e 4, a e 5 . \\
\text { ss, df, wl. } \\
\text { ae4, ae6 } \\
\text { Sbp, Fb, Fl, dc, wl }\end{array}$ & $0.4 \mathrm{~m}$ & $\begin{array}{l}\text { Chrintz and Clemmensen (1993) } \\
\text { Mountney (2012) } \\
\text { Rodriguez-López et al. (2011) } \\
\text { Brookfield (1992) } \\
\text { Loope (1988) } \\
\text { Hasiotis (2002) } \\
\text { Mountney (2006) }\end{array}$ \\
\hline
\end{tabular}




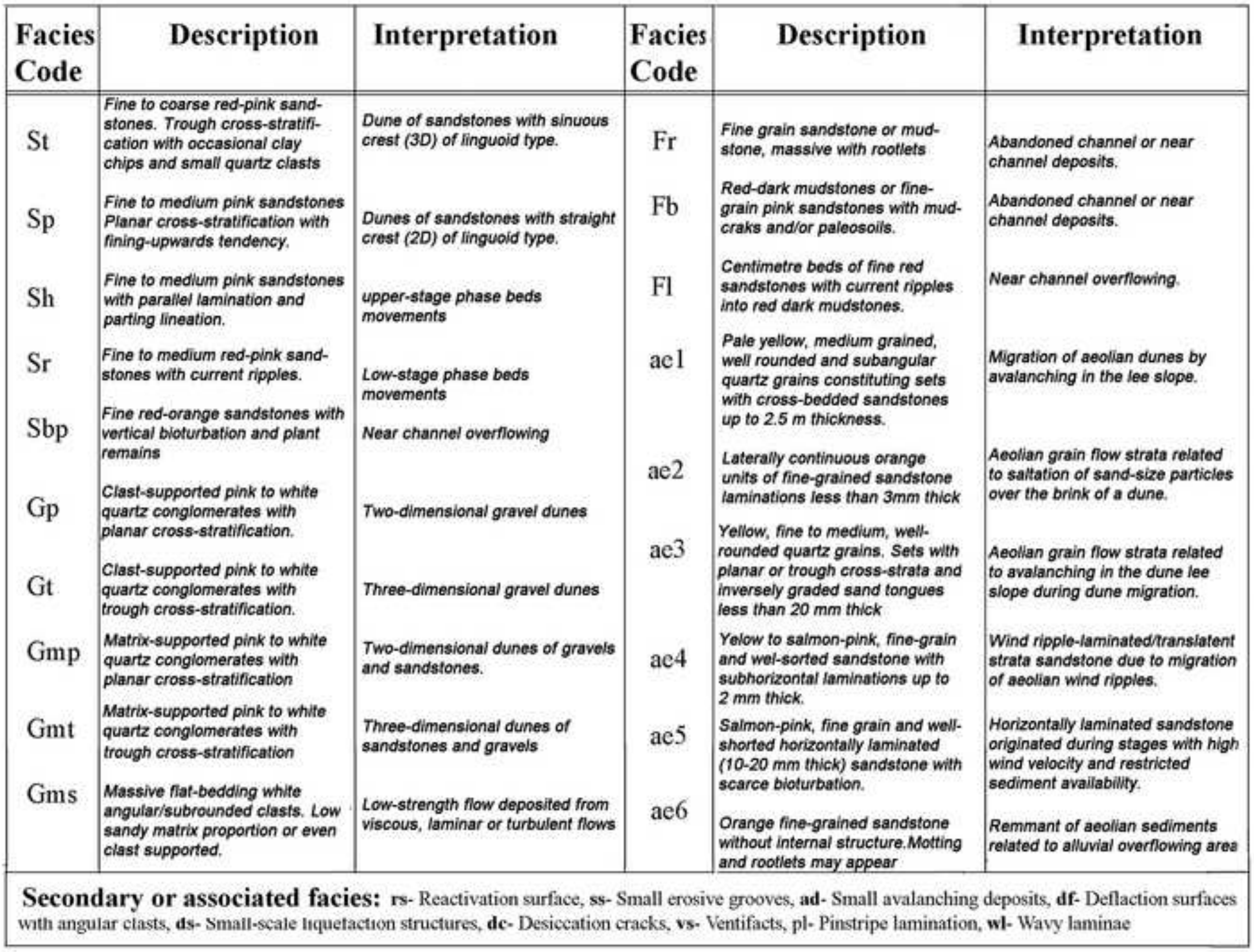



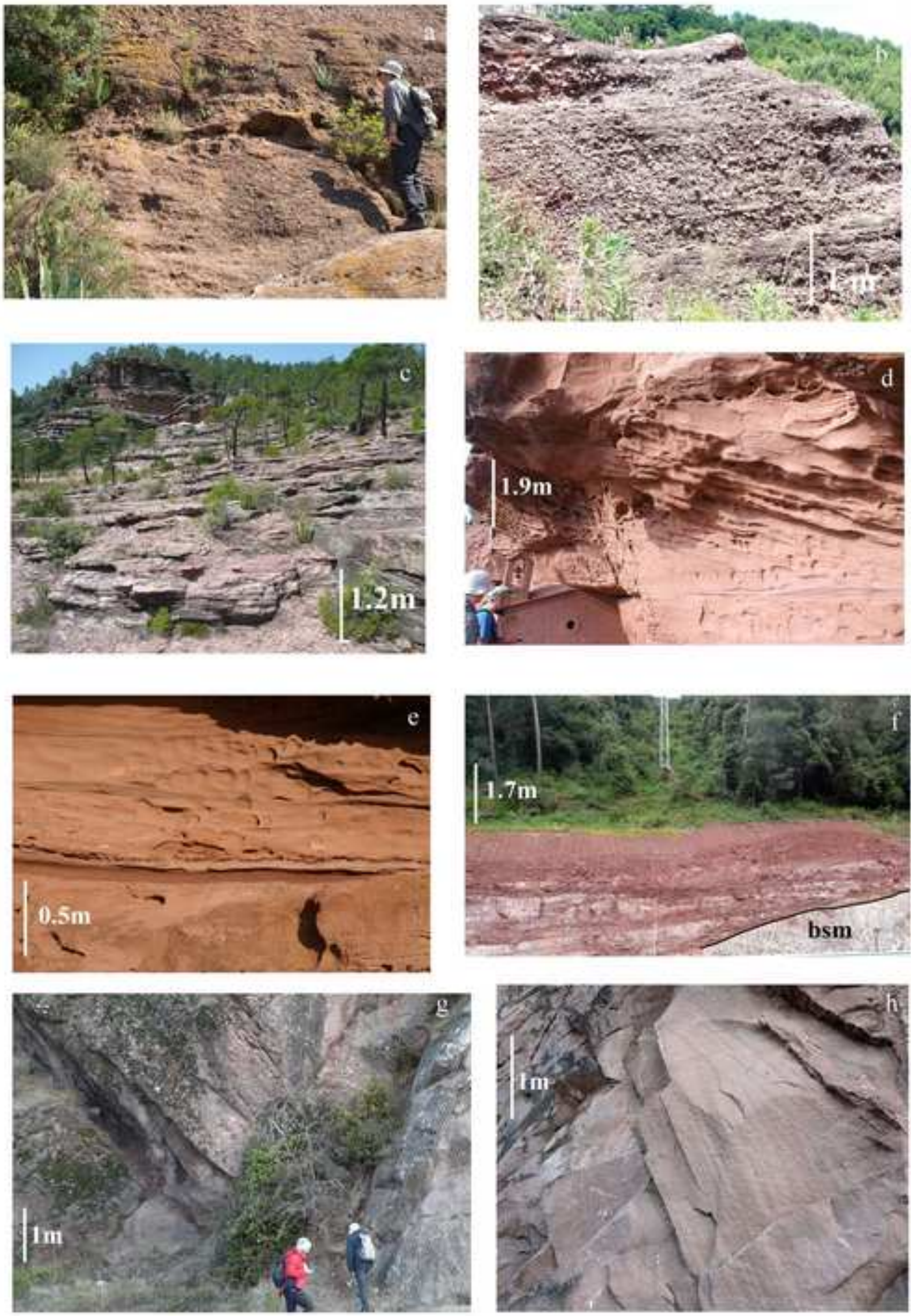

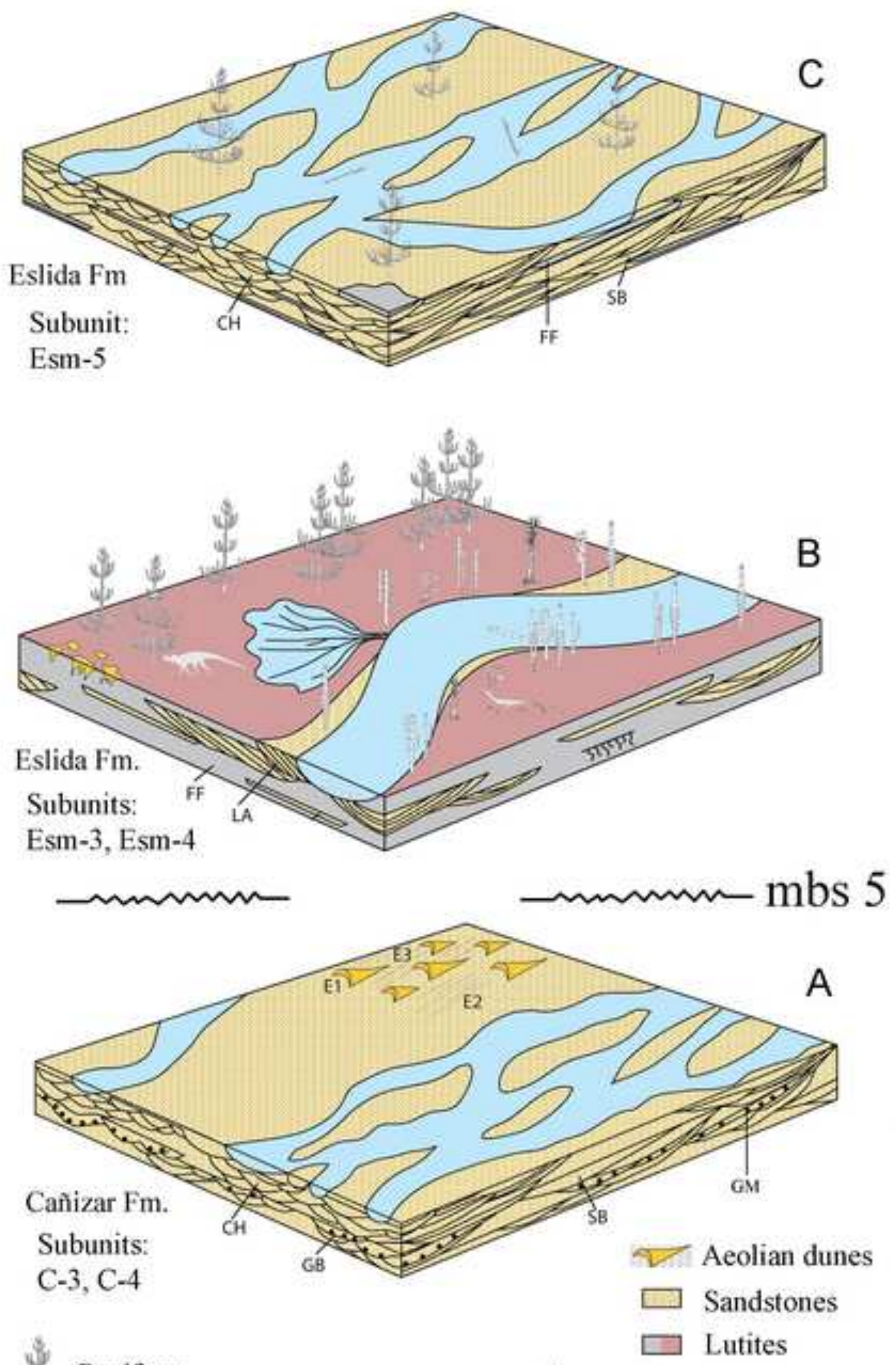

Conifers:
Voltzia and or Albertia \& Pelourdea Pleuromeia Sphenophytes 
Click here to download high resolution image

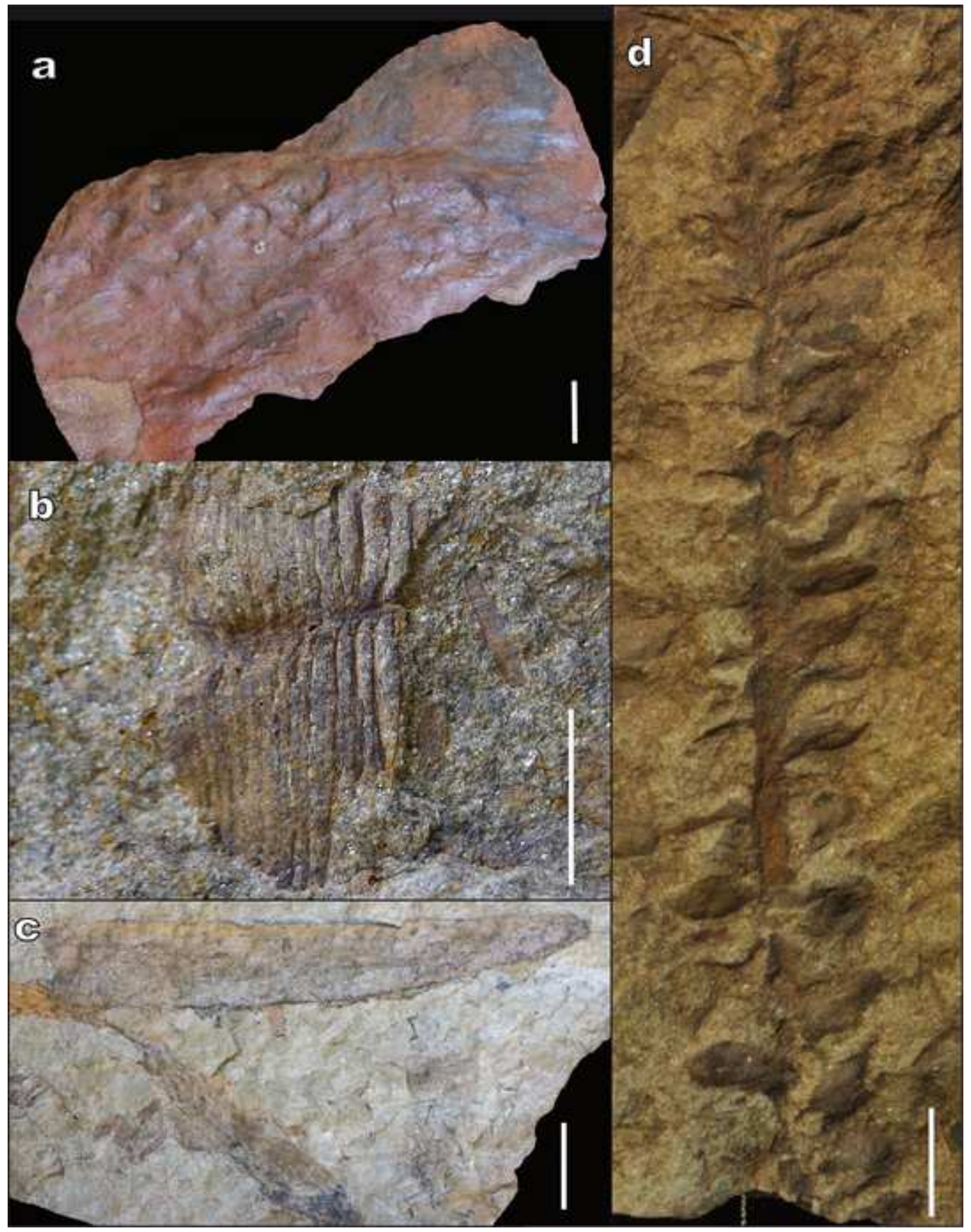


Click here to download high resolution image
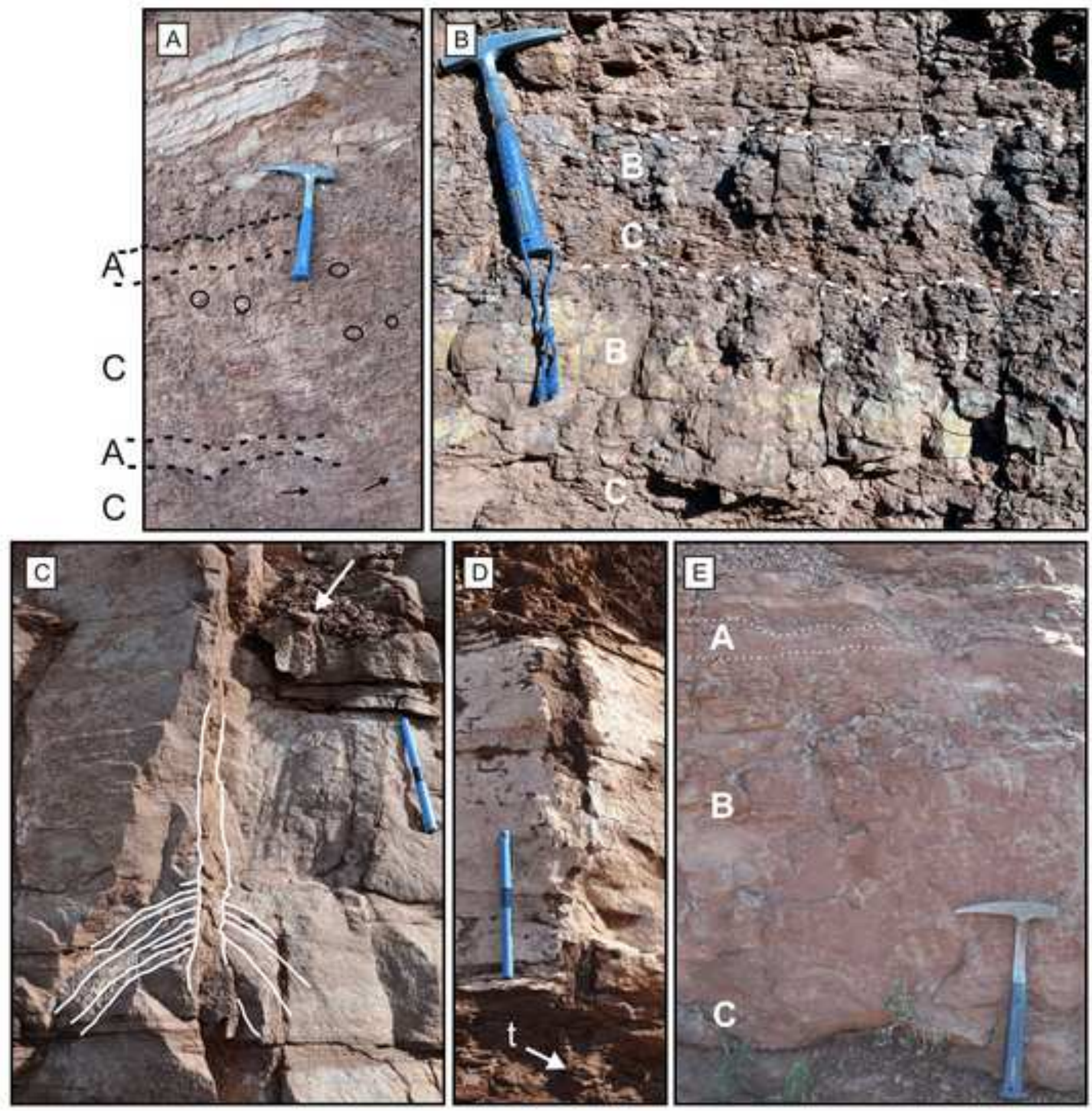

B

C 


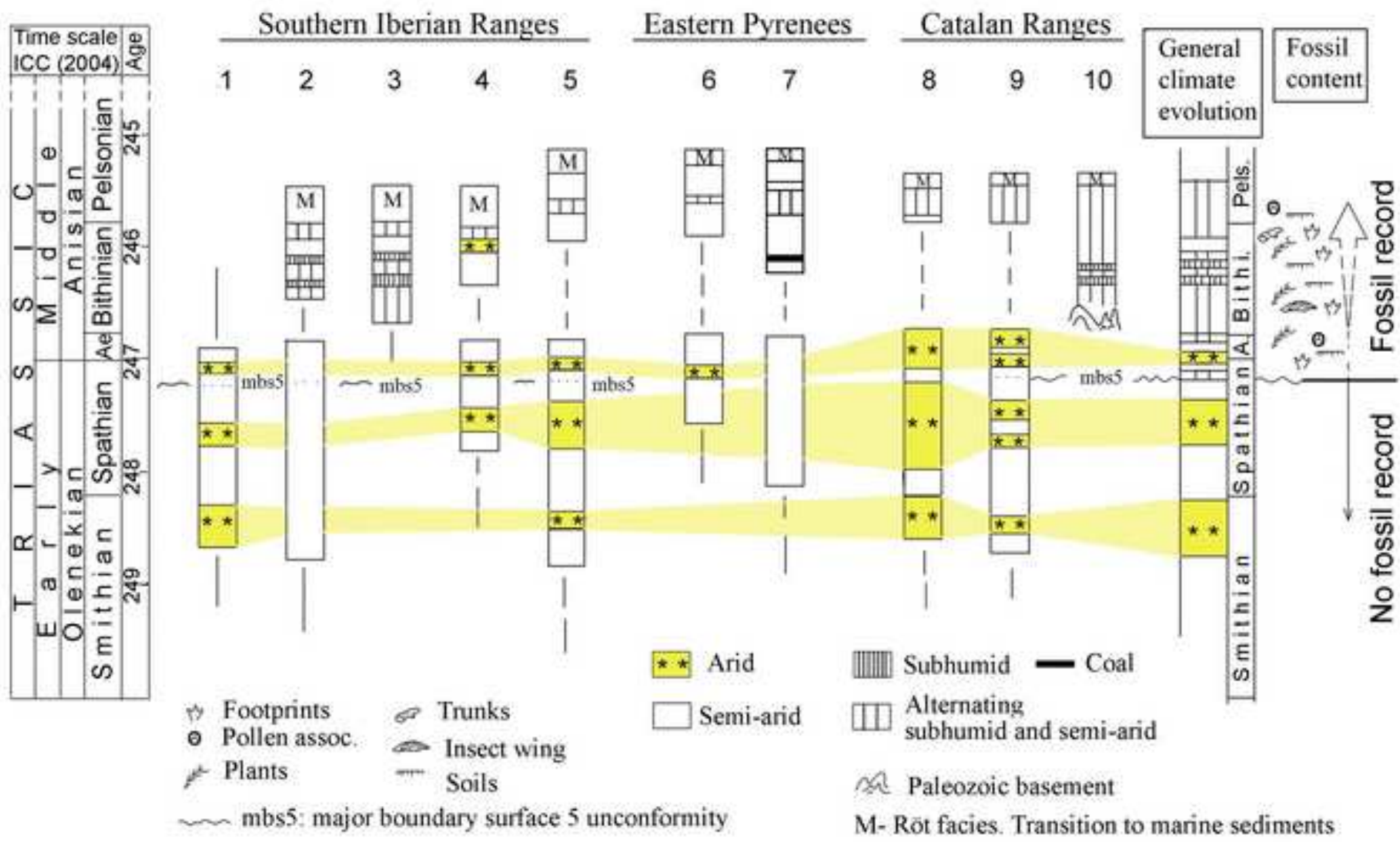


AC-Armorica

AMh-Ateca-Montalbán High

C- Corsica

Ca- Cabilia

$\mathrm{Cb}-$ Catalan basin

Scv- Scandinavia

Eh- Ebro High

Gb-Grand Banks

Gh- Girona High

Gr-Greenland

$\mathrm{HH}-\mathrm{Hatton}$ High

IB- Iberia

IM- Irish Massif

M- Majorca

Mi- Minorca

P-Provence

$\mathrm{Pb}$ - Pyrenean basin

Rh- Rhenish High

VH- Vindicelian High

$\Delta$

Continental

Aeolian dominant

$\therefore$ Fluvial

Land masses
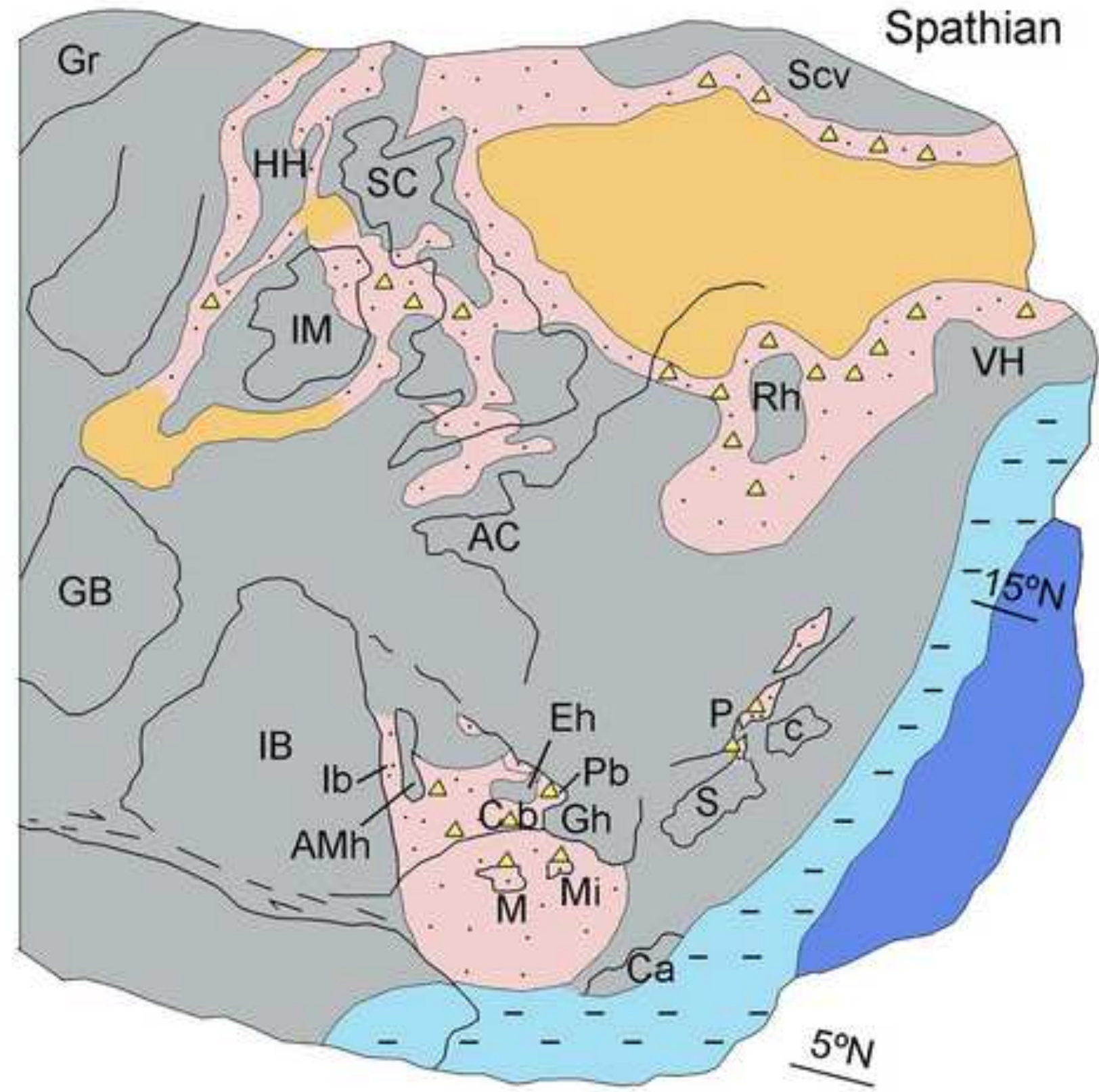

$\begin{array}{ll}\text { Playa lake } \quad- & \begin{array}{l}\text { Shallow marine } \\ \text { Mainly siliciclastics }\end{array}\end{array}$
Marine carbonates 


\section{Figure captions}

Fig. 1. Early Triassic global map showing the configuration of the continents (modified from Golonka and Ford, 2000; Yin and Song, 2013). The amplified area corresponds to the Iberian peninsula and the present-day basin and ranges: 1- Pyrenean Ranges, 2Catalan Ranges, 3- Ebro Basin, 4- Duero Basin, 5Iberian Ranges, 6- Tagus Basin, 7Guadalquivir Basin, 8- Betic Ranges, 9- Iberian Massif, 10- Balearic Islands.

Fig. 2. Lithostratigraphic scheme of the Middle Permian - Middle Triassic units of the studied areas and their comparison with coeval units of NE Sardinia and Minorca. Numbers 1 to 12 represent sections cited in the text: 1- Río Mayor, 2- Gátova, 3Cedrillas-Corbalán, 4- Torre de Las Arcas - Peñarroyas, 5- Benicassim, 6- Novés, 7Castellar d’Hug, 8- San Gregori, 9: Cervelló, 10- El Brull-Figaró, 11- Cala Pilar, 12Cala Viola. Their geographical location are indicated down to the right in the figure.

Fig. 3. a) The Cañizar Fm. in S. Iberian Ranges. Lines represent major boundaries surfaces (MBS) and separate subunits (A to F). The lower contact is an unconformity that separates the Triassic to the Permian (Alcotas Fm.) (Photograph modified from López-Gómez et al., 2012). b) The Eslida Fm. in the E Iberian Ranges.

Fig. 4. Main characteristics and references of the lithological units of the studied areas.

Fig. 5. Studied Lower-Middle Triassic sections and their main sedimentary and paleontological characteristics of the S. Iberian Ranges, E. Pyrenees and Catalan Ranges. Their geographical locations are indicated in figure 2. Description of the 
architectural elements is shown in figure 7. $\mathrm{C} 1$ to $\mathrm{C} 6$ and Ems-3 to Ems-6 represents subunits of the Cañizar Fm. and Eslida Fm. respectively.

Fig. 6. Description, interpretation and codes of the main and secondary fluvial and aeolian facies.

Fig. 7. Fluvial and aeolian architectural elements showing their codes, facies associations, hierarchy and vertical stacking patterns, and selected references.

Fig. 8. Pictures of the different described architectural elements: a) element GB in the Garraf Upper Conglomerates Unit (GUC), Catalan Ranges; b) element GM in the Prades Upper Conglomerates Unit (PUC), Catalan Ranges; c) SB and CH elements in the Cañizar Fm. (CS), Iberian Ranges; d) E1 element in Prades Lower Sandstone Unit (PLS), Catalan Ranges; e) E2 and E3 elements in Prades Lower Sandstone (PLS), Catalan Ranges; f) FF element in Figaró Sandstones and Mudstones (FSM), Catalan Ranges; f) GB element in the lowermost part of the "Buntsandstein" deposits of the Noves section, Pyrenean Ranges; h) E1 element in the lower Buntsandstein of the Noves section, Pyrenean Ranges. See figure 5 for the location of these units and sections.

Fig. 9. Sketches of 3D evolution of three selected stages of the Buntsandstein of the Iberian Ranges showing alluvial evolution and macroflora distribution (modified from Borruel-Abadía et al., 2014). 
Fig. 10. Specimens of macroflora from the Eslida Fm. in the Iberian Ranges. a: Pleuromeia sternbergii (Münster) Corda ex Giebe, 1953; b: Sphenophytes, most likely Equisetitesmougeotii Brongniart 1828; c: Pelourdea vogesiaca (Schimper et Mogeot) Seaward 1917; d: Albertia latifolia Schimper et Mougeot 1944. Scale bar: $1 \mathrm{~cm}$.

Fig. 11. A) Dispersed carbonate nodules are circled in the subsurface horizon of the Gat-A pedotype. Black arrows are pointing to small green root traces. B) Calcareous, rooted, and endurated yellow B horizons are irregularly truncated in the Pedotype GatB. C) Adventitious prop roots (marked in white) emanating from a main root in the GatC pedotype. White arrow is pointing to the top of another unmarcked prop root pattern. D) Deep penetrating tap root with root apex (r) related to Gat-C paleosols. E) Drabhaloes of light green silt around root traces in the pedotype Gat-D.

Fig. 12. Synthesis of the main climate stages and their vertical alternating disposition during the Smithian to Pelsonian time - interval in the continental units (Buntsandstein) of the S. Iberian Ranges, E. Pyrenees and Catalan Ranges, and their relationship with fossil content. Sections (numbers 1 to 10) are located and named in figures 2 and 5.

Fig. 13. Early Triassic palaeogeographical reconstruction of Iberia and neighbour areas. Basins in Iberia were separated by elevated areas linked to the development of rift systems. Palaeolatitudes and sedimentary environments are partially based on Ziegler (1988), Dercourt et al. (1993), Mckie and Williams (2009), Bourquin et al. (2011) and Tyrrell et al. (2012). 
Dear Editor,

In attached files (Revision Notes, Revision changes marked and Clean version) you will find the revised version of manuscript PALAEO8729 "Climate changes during the Early-Middle Triassic transition in the E. Iberian Plate and its palaeogeographic significance in the western Tethys continental domain", by Borruel-Abadía et al.

First of all, we'd like to thank the detailed and interesting comments and recommendations sent by the reviewers and the Editor, as we consider all of them will improve the final version of this manuscript. All of them have been followed and carefully included in the final (clean) version and shown, one by one, in the "Revision, changed marked" item.

Reviewer 1 sends a short list of interesting comments and recommendations, most of them (his points 5, 6, 7, 8 and 9) basically concentrated in two main topics that have needed a more detailed discussion. They are: a) the taphonomic biases of the paleobotanical record, and b) about what was driving the inferred climate changes (the case of the tectonics). This latter topic is also commented by reviewer 2 . For answering these points, new paragraphs (as indicated in the Revision Notes) have been added.

Other aspects written by reviewer 1 (a total of 7 more, as the information published in some $\mathrm{H}$. Bucher's papers, the influence of the Muschelkalk transgression, miss-spelled words....) are also of interest and answered here by the authors.

Reviewer 2 concentrates his comments and recommendations in 4 main points. Points 1,2 and 4 basically recommends a reorganization in some paragraphs of the "Results - Discussion and Conclusion" chapters, as well as to reduce the length of the text eliminating some repetitions and by means of the own reorganization above suggested. These changes have needed more detailed (reorganization)modifications in the text, as is also shown in the "Revision, changed marked" item and therefore in the Clean version. The final result is clearly better than the original version. However the final length is not reduced as new paragraphs and references have been included, as suggested by both referees, for explaining other points.

In the "Revision, changed marked item", the added words/paragraphs suggested by the reviewer 1 are indicated in blue, and those suggested by reviewer 2 are indicated in green, while those eliminated are shown in red. All of these changes are also explained in the Revision Notes item.

Thank you again.

Kind regards, José López-Gómez 